\title{
EL CONVENIO 169 DE LA OIT SOBRE PUEBLOS INDÍGENAS Y TRIBALES \\ DERECHO INTERNACIONAL Y EXPERIENCIAS \\ COMPARADAS
}

\section{Elina Mereminskaya}

Este artículo indaga la génesis del Convenio 169 de la OIT relativo a los derechos de los pueblos indígenas y tribales, y describe las obligaciones para los países que lo han ratificado. Se señala que la labor de la OIT en la promoción de estos derechos ha estado permanentemente acompañada de cuestionamientos a su competencia y a lo que ha sido considerado, a veces, un excesivo activismo de su Secretariado. Sin embargo, tanto el Convenio 169 como su instrumento antecesor fueron aprobados con una importante votación a favor. Una situación semejante ocurrió en Chile al ratificarse el Convenio 169 por amplia mayoría después de dieciocho años de tramitación en el Congreso.

Se advierte que si bien la OIT no es un órgano jurisdiccional, sus pronunciamientos permiten apreciar el vasto alcance de las obligaciones que asumen los Estados firmantes en lo que se refiere a la necesidad de incluir a los pueblos indígenas en los procesos de toma de decisiones de todas las medidas que

Euina Mereminskaya. Doctora y Magíster en Derecho, Universidad de Göttingen, Alemania. Abogada, Universidad Rusa de Immanuel Kant, Rusia. Consejera Especial para Arbitraje Internacional, Centro de Arbitraje y Mediación de la Cámara de Comercio de Santiago. 
les conciernan, así como en lo que atañe a los derechos de propiedad, de uso de tierras y de recursos naturales. A modo de ilustración, se presentan las políticas públicas que en base al Convenio 169 han sido implementadas en tres países: Noruega, México y Argentina.

Palabras clave: Pueblos indígenas y tribales; Convenio 169; OIT; implementación de tratados internacionales.

Recibido: junio 2010. Aceptado: julio 2010.

\section{Introducción}

$\mathrm{C}_{1}$ presente artículo analiza el Convenio 169 sobre pueblos indígenas y tribales de la OIT (Organización Internacional del Trabajo) desde una perspectiva histórica y comparada. Como este instrumento internacional ya es derecho vigente en Chile, pasamos por alto la pregunta acerca de la conveniencia de su ratificación y nos enfocamos en cambio en sus repercusiones para el ordenamiento jurídico nacional. Para ello (1) nos aproximaremos al Convenio 169 desde la perspectiva de su génesis histórica, la que se complementará con algunas reflexiones acerca de su lugar en la regulación internacional de los derechos de los pueblos indígenas. Luego (2), para comprender los alcances de las disposiciones más relevantes del Convenio, recurriremos a las interpretaciones efectuadas por los órganos de la OIT; veremos allí manifiestas discrepancias entre las expectativas de la OIT y las visiones de los gobiernos nacionales encargados de su implementación. Por último (3), nos detendremos en algunos países que han ratificado el Convenio 169 a fin de mostrar una diversidad de acciones susceptibles de ser tomadas y que, al mismo tiempo, ilustran lo complejo que resulta alcanzar los estándares contemplados en ese tratado. El trabajo termina (4) con conclusiones relativas a cómo debería Chile afrontar el proceso de implementación del Convenio 169.

\section{EL CONVENIO 169 DE LA OIT EN EL CONTEXTO}

DE REGULACIÓN INTERNACIONAL DE LOS DERECHOS INDÍGENAS

El reconocimiento de los derechos de los pueblos indígenas constituye uno de los hitos más recientes en el desarrollo del derecho internacional público. El tema tiene sus raíces históricas en la coloni- 
zación del continente americano y africano por parte de las potencias europeas y se consolida definitivamente en la agenda internacional con el desmantelamiento del sistema colonial después de la Segunda Guerra Mundial.

Al comienzo de los procesos de colonización las naciones europeas eran reacias a reconocerles a los pueblos indígenas recién descubiertos la calidad de sujetos de derecho internacional. En algunos casos, los poderes colonizadores celebraron tratados con los habitantes nativos. Aunque ésta nunca fue la política de España ni de Portugal ${ }^{1}$, sí ocurrió en los territorios de Canadá y Nueva Zelanda ${ }^{2}$. Sin embargo, tales acuerdos no tenían la fuerza de tratados internacionales, que únicamente pueden suscribirse entre "dos poderes independientes" 3 . La toma de posesión de los nuevos territorios se justificaba, más bien, con la "doctrina de descubrimiento", lo que además aseguraba los títulos de posesión frente a las otras naciones europeas ${ }^{4}$. De esta manera se entabló la ficción legal internacional de que las tierras indígenas constituían terra nullius; un ejemplo característico de ello es el caso de los territorios de Australia ${ }^{5}$. Con la instauración del sistema westfaliano de Estados nacionales, la calidad de sujetos del derecho internacional se restringió a Estados organizados de conformidad con el modelo europeo, caracterizado por el dominio territorial y la presencia de una autoridad jerárquica. Con ello se consagra la marginación de los pueblos indígenas del derecho internacional, cuyo estatus jurídico pasa a ser un asunto interno de los miembros de la comunidad internacional. De conformidad con la noción de soberanía estatal, toda intervención foránea en materias internas se encuentra limitada, con lo cual el trato otorgado a los pueblos originarios no es susceptible de un escrutinio desde el exterior $^{6}$.

${ }^{1}$ Jeff J. Corntassel y Tomas Hopkins Primeau, “Indigenous 'Sovereignty' and International Law: Revised Strategies for Pursuing 'Self-Determination'”, 1995, p. 354.

2 John Borrows, "Ground-Rules: Indigenous Treaties in Canada and New Zealand", 2006, pp. 188-189.

${ }^{3}$ Patrick Macklem, "Indigenous Recognition in International Law: Theoretical Observations", 2008, p. 185.

${ }^{4}$ Jeff J. Corntassel y Tomas Hopkins Primeau, "Indigenous 'Sovereignty' and International Law: Revised Strategies for Pursuing 'Self-Determination’”, 1995, p. 354.

${ }^{5}$ Sheryl R. Lightfoot, "Indigenous Rights in International Politics: The Case of 'Overcompliant' Liberal States”, 2008, p. 92.

${ }^{6}$ James S. Anaya, Los Pueblos Indigenas en el Derecho Internacional, 2005 , pp. $48-71$. 
Con la creación de la Organización de las Naciones Unidas (ONU) el derecho de todos los pueblos a la libre determinación es reconocido en el plano internacional (artículos 1 y 55, Carta de la ONU) y el proceso de descolonización recibe un potente impulso. Sin embargo, la Resolución 1541 del 15 de diciembre de 1960, aprobada por la Asamblea General de la ONU, acoge la denominada doctrina de "agua azul" o de "agua salada", acorde a la cual el objetivo de descolonización únicamente puede ser perseguido por "un territorio que está separado geográficamente del país que lo administra y es distinto de éste en sus aspectos étnicos o culturales"'. De acuerdo a esta definición, los pueblos indígenas habitantes de países independientes se encuentran fuera de la cobertura del principio señalado. Por otro lado, en la práctica de la ONU, el derecho a la libre determinación es propio de los pueblos colonizados, dominados por una potencia extranjera. En cambio no procede su ejercicio en contra de los Estados independientes que actúen de conformidad con las normas y principios de la Organización; no puede ser usado como pretexto para atentar contra la integridad territorial de un Estado y, asimismo, su ejercicio no corresponde a las minorías, cuya protección se instaura a través de instrumentos internacionales ${ }^{8}$. El tratamiento actual del tema de los derechos indígenas se enmarca entonces en esa realidad de negar el reconocimiento a esos pueblos y a sus antecesores como actores soberanos: "Lo que transforma a los pueblos indígenas en actores del ordenamiento internacional es, en otras palabras, la estructura y el operar del derecho internacional mismo".

A continuación (1.1) trazaremos las líneas históricas que permiten comprender la génesis del mandato que le fue otorgado a la OIT para dedicarse a la regulación de los temas indígenas. Explicaremos (1.2) el modelo subyacente en el instrumento internacional antecesor del Convenio 169 y su transformación hacia el formato actual. Luego (1.3) haremos unas breves referencias al contexto general de protección de los derechos indígenas, con el fin de apreciar el papel que cumple el

${ }^{7}$ Organización de las Naciones Unidas (ONU), Resolución 1541 (XV) de la Asamblea General, Principio IV: "Principios que deben servir de guía a los Estados Miembros para determinar si existe o no la obligación de transmitir la información que se pide en el inciso E del Artículo 73 de la Carta".

${ }^{8}$ Rodolfo Stavenhagen, "Los Derechos Indígenas en el Sistema Internacional: Un Sujeto en Construcción”, 1998, pp. 92-93.

${ }^{9}$ Patrick Macklem, "Indigenous Recognition in International Law: Theoretical Observations", 2008, p. 180. 
Convenio 169 en el sistema del derecho internacional. Por último (1.4), nos referiremos al proceso de incorporación del Convenio 169 al derecho chileno.

\subsection{EI mandato de la OIT para regular los derechos indígenas}

La Organización Internacional del Trabajo (OIT) fue creada en 1919 como parte del Tratado de Versalles que puso fin a la Primera Guerra Mundial. La institución posee una estructura tripartita, única para una organización internacional, en la cual los actores no estatales - empleadores y trabajadores - reciben un estatus igual al de sujetos plenos del derecho internacional. Dicha estructura refleja el momento histórico de su creación y constituye un intento por establecer un camino alternativo al socialismo soviético, mejorando los estándares laborales e incorporando a los sindicatos en el proceso de su definición ${ }^{10}$. No obstante que el sistema establecido por la Liga de Naciones quedó sin efecto a causa de la Segunda Guerra Mundial, la OIT recibió un impulso a sus actividades a través de su Conferencia de Filadelfia del año 1944, que consagró una Carta de propósitos y objetivos de la OIT consolidando su rol como entidad articuladora de los estándares internacionales en materia laboral ${ }^{11}$. En 1946, la OIT se convirtió en una agencia especializada de la recién creada Organización de las Naciones Unidas.

Hoy en día pueden encontrarse críticas a la OIT que apuntan a su supuesta disminuida capacidad de participar en los procesos de determinación de estándares laborales internacionales y de adaptarse a la realidad contemporánea ${ }^{12}$. Más allá de estas críticas, cabe destacar que el funcionamiento de la OIT tradicionalmente se ha caracterizado por un liderazgo fuerte del Secretariado (Oficina Internacional del Trabajo). Así, a lo largo de casi un siglo, la Oficina ha sabido incorporar a la agenda organizacional temas y prácticas novedosas, fundamentando tal necesidad con un discurso valórico y argumentos técnicos, los que final-

${ }^{10}$ Laurence R. Helfer, "Understanding Change in International Organizations: Globalization and Innovation in the ILO”, 2006, pp. 679-681.

${ }^{11}$ Wilfrid Benson, “An I.L.O. Pattern for Pacific Territories”, 1944, pp. 311-319.

12 Gay Standing, "ILO: An Agency for Globalization?", 2008, pp. 355-384; Philip Alston y James Heenan, "Shrinking The International Labor Code: An Unintended Consequence of the 1998 ILO Declaration on Fundamental Principles and Rights at Work?", 2004, pp. 5-33; Alan Hyde, "The International Labor Organization in the Stag Hunt for Global Labor Rights”, 2009, pp. 153-179. 
mente han encontrado la aprobación de los miembros constituyentes ${ }^{13}$. Lo anterior nos acerca a la pregunta acerca de cómo un tema de índole tan transversal como los derechos indígenas llegó a formar parte del quehacer de esa institución.

La regulación de los derechos de los pueblos indígenas y tribales emerge en la agenda internacional a fines del siglo XIX. Así, el Acta General de la Conferencia de Berlín sobre África Occidental del año 1885, dedicada en su esencia a la división de los territorios africanos entre las potencias coloniales europeas, incorporó en su artículo $\mathrm{VI}^{\mathrm{o}}$ el compromiso de los Estados signatarios de preocuparse por "la conservación de las poblaciones indígenas, la mantención de su moral y sus condiciones materiales".

Más adelante, el artículo 22 del Tratado de la Liga de Naciones consagró que en ciertos territorios pertenecientes previamente a los poderes vencidos en la Primera Guerra Mundial, "habitados por pueblos incapaces aún de subsistir por sí mismos en las condiciones de la intensa vida moderna", la tutela sobre estos últimos se confiara a las "naciones adelantadas". El precepto dividió los territorios en tres grupos (A, B y C) acorde a su nivel de desarrollo, y para los dos últimos (B y C), que abarcaban los países de África central, sudeste de África y algunas islas del Pacífico austral, se establecieron ciertos criterios de trato por parte de la nación administradora hacia la población sometida a su mandato. Dichos estándares incluyen la garantía de la libertad de conciencia y religión, con la salvedad del mantenimiento del orden y moral públicos, y la prohibición del tráfico de esclavos, armas y bebidas alcohólicas. En el artículo $23^{\circ}$ del Tratado, los miembros de la Liga "se comprometen a asegurar un trato justo para los indígenas habitantes de los territorios que se hallen bajo su autoridad" (letra b). Sin perjuicio de ello, la colaboración de los poderes fundadores con la Comisión de Mandatos establecida de conformidad con el artículo 22 no era entusiasta, siendo ellos de la opinión que el día a día de la administración de los mandatos se encontraba completamente dentro de su competencia y al margen del poder de intervención de la Liga ${ }^{14}$.

${ }^{13}$ Laurence R. Helfer, "Understanding Change in International Organizations: Globalization and Innovation in the ILO”, 2006, p. 689.

${ }^{14}$ Daniel Groman, "Liberal Internationalism, the League of Nations Union, and the Mandates System”, 2005, pp. 462-472. 
Por otro lado, en el Capítulo XII del Tratado de Paz de Versalles, que creó la Organización Internacional de Trabajo, se estipuló el compromiso de los Estados signatarios de aplicar los convenios suscritos en el ámbito laboral a sus colonias, protectorados y posesiones que no eran totalmente autónomos en su administración (art. 421). La obligación estaba sujeta a la excepción y hacía los convenios inaplicables o sujetos a modificaciones necesarias debido a las "condiciones locales". Los miembros del Tratado tenían la obligación de notificar a la Oficina Internacional de Trabajo de las acciones que tomaren de conformidad con esas normas. No obstante, la facultad de adaptar la aplicación de los convenios a las condiciones locales se constituyó en una amplia cláusula de escape para los Estados signatarios, quienes no mostraban la disposición de someterse a cualquier tipo de supervisión por parte de la OIT $^{15}$.

Sin embargo, la Oficina logró a la brevedad obtener un asiento en la Comisión de Mandatos, posición desde la cual comenzó a ampliar sus incipientes funciones de supervisión, y no tan sólo en los territorios administrados a través del sistema de los mandatos, sino que en todos los territorios bajo el poder de las metrópolis europeas. Una de las primeras iniciativas de la Oficina en ese contexto consistió en impulsar estudios sobre la situación de los trabajadores indígenas ${ }^{16}$. Al mismo tiempo, participó en el Comité Temporal sobre la Esclavitud, obteniendo en el año 1925 un mandato implícito de la Asamblea de la Liga para regular la prevención del trabajo forzado semejante a la esclavitud ${ }^{17}$. Durante el período previo a la Segunda Guerra Mundial, bajo los auspicios del organismo fueron elaborados una serie de convenios y recomendaciones relativos a las condiciones laborales de los pueblos nativos de las colonias, llamados el "Código Colonial". Con posterioridad, esa normativa fue revisada y reforzada con el apoyo de la ONU, culminando la Agenda Colonialista de la Organización con la aprobación del Convenio 105 sobre la abolición del trabajo forzado en 1955 y del Convenio 107 sobre poblaciones indígenas y tribales en $1957^{18}$.

${ }^{15}$ Luis Rodríguez-Piñero, Indigenous Peoples, Postcolonialism and International Law: The ILO Regime (1919-1989), 2006, pp. 24-25.

${ }^{16}$ Ibíd., pp. 28-29.

${ }^{17}$ Ibíd., pp. 31-32.

${ }^{18}$ Ibíd., pp. 32-38. 


\subsection{Del Convenio 107 al Convenio 169: de la integración a la autonomía}

La elaboración del Convenio 107 fue antecedida por un activo despliegue por parte de la OIT de una serie de estudios, programas y políticas de desarrollo indigenista, que se extendieron a lo largo de los años treinta y cincuenta del siglo pasado. El ámbito geográfico de actuación de la OIT en esa época se centraba en América Latina, con particular énfasis en los países andinos ${ }^{19}$. Para consagrar los estándares de trato hacia los pueblos indígenas, la Secretaría inicialmente planteó la posibilidad de aprobar una Recomendación, esto es, un instrumento no vinculante de índole técnica destinado a servir como guía para las políticas públicas de los países miembros. Sin embargo, la Conferencia Internacional de Trabajo — después de discutir si la Organización era o no competente para crear semejante normativa - votó mayoritariamente a favor de transformar el documento en un Convenio y reservar los aspectos más sensibles para una Recomendación, la cual fue aprobada bajo el título de la Recomendación 104 sobre poblaciones indígenas y tribales ${ }^{20}$. Los pueblos indígenas no estuvieron representados en la negociación y redacción del texto del Convenio, razón por la cual el Segundo Congreso Mundial de Pueblos Indígenas, realizado en el año 1977, resolvió "rechazar totalmente" el Convenio 107 y la Recomendación $104^{21}$.

Acorde con lo señalado en el art. $1^{\circ}$, el Convenio se aplicaba, en primer lugar, a miembros de poblaciones tribales o semi-tribales en países independientes, cuyas condiciones sociales y económicas eran inferiores a las de otros sectores de la sociedad y cuyo estatus se regulaba total o parcial por sus propias leyes. En segundo lugar, se refería a miembros de poblaciones tribales o semi-tribales en países independientes, considerados indígenas en virtud de su procedencia de los pueblos originarios durante la época de conquista o colonización, y que preservaban su forma de vida conforme a la existente en aquel período. En efecto, el Convenio cubría dos categorías de poblaciones tribales, una considerada indígena y otra no. Pero en ambos casos el elemento

${ }^{19}$ Ibíd., pp. 53-122.

${ }^{20}$ Ibíd., pp. 129-138.

${ }^{21}$ Chris Tennant, "Indigenous Peoples, International Institutions, and the International Legal Literature from 1945-1993”, 1994, p. 48. 
central de la definición era el grado de integración de esas poblaciones dentro de la comunidad nacional ${ }^{22}$.

El Convenio 107 rechaza la asimilación artificial y forzada de los indígenas, pero aboga por su pronta integración. Sus términos son consistentes con la idea de integración, sostenida en los postulados antropológicos vigentes en su época. La protección es concebida como un proceso progresista de ajuste cultural, que permite a través del desarrollo económico y social reforzar la legitimidad y eficacia de la institucionalidad del Estado $^{23}$. Las principales herramientas del Convenio 107 son la educación y el entrenamiento profesional, los que permitirían a los indígenas incorporarse a las fuerzas laborales de los países ${ }^{24}$. Con ello, la protección internacional hacia las personas indígenas se concibe en términos temporales y transitorios ${ }^{25}$, necesaria tan sólo durante el período que se requiera para completar su integración a las sociedades nacionales y superar su estado de segregación ${ }^{26}$.

La cooperación técnica desplegada por la OIT para guiar a los 29 países signatarios en sus programas de integración y promoción del desarrollo de sus poblaciones indígenas nunca ha podido producir efectos en la práctica ${ }^{27}$. La idea de revisar el Convenio 107 surgió desde el Secretariado de la OIT y fue impulsada, en parte, por el de-

${ }^{22}$ Luis Rodríguez-Piñero, Indigenous Peoples, Postcolonialism and International Law: The ILO Regime (1919-1989), 2006, p. 164.

23 Patrick Macklem, "Indigenous Recognition in International Law: Theoretical Observations", 2008, p. 194. Véase el art. 6 del Convenio 107: "El mejoramiento de las condiciones de vida y de trabajo, así como del nivel educativo de las poblaciones en cuestión, deberá ser objeto de alta prioridad en los planes globales de desarrollo económico de las regiones en que ellas habiten. Los proyectos especiales de desarrollo económico que tengan lugar en tales regiones deberán también ser concebidos de suerte que favorezcan dicho mejoramiento".

${ }^{24}$ Chris Tennant, "Indigenous Peoples, International Institutions, and the International Legal Literature from 1945-1993”, 1994, p. 26.

${ }^{25}$ Véase, por ejemplo, el art. 3 del Convenio 107: "1. Se deberán adoptar medidas especiales para la protección de las instituciones, las personas, los bienes y el trabajo de las poblaciones en cuestión mientras su situación social, económica y cultural les impida beneficiarse de la legislación general del país a que pertenezcan. 2. Se deberá velar por que tales medidas especiales de protección: a) no se utilicen para crear o prolongar un estado de segregación; y b) se apliquen solamente mientras exista la necesidad de una protección especial y en la medida en que la protección sea necesaria".

${ }^{26}$ Patrick Macklem, "Indigenous Recognition in International Law: Theoretical Observations", 2008, p. 194.

${ }^{27}$ Luis Rodríguez-Piñero, Indigenous Peoples, Postcolonialism and International Law: The ILO Regime (1919-1989), 2006, pp. 216-233. 
seo de mantener el liderazgo de la regulación internacional sobre el tema, que la Organización consideraba tradicionalmente propio. Al principio, esa iniciativa se enfrentó con la oposición del Grupo de Trabajo de la ONU sobre las Poblaciones Indígenas. Sin embargo, la labor de este último mostraba sólo leves avances, motivo por el cual la OIT finalmente obtuvo el beneplácito de la ONU para seguir con la regulación del tema, entendiendo que lo haría de la manera "técnica" que la caracterizaba ${ }^{28}$.

El paradigma del nuevo texto abandonó definitivamente el proyecto de integración y mestizaje. En efecto, el Secretariado, acorde con las tendencias y discursos de la época y apoyado por el Comité de Expertos a cargo de la revisión, declaró "destructivo" el concepto de integración ${ }^{29}$. En el Comité tripartito ad hoc para la revisión del Convenio 107 que analizó la propuesta del Secretariado, se desarrollaron arduas polémicas sobre el alcance de tres nociones particularmente sensibles. Así, a juicio del Secretariado, el concepto de "pueblos indígenas" era preferible por encontrarse en sintonía con la terminología del derecho internacional y con aquella empleada por los propios grupos indígenas. A la luz de las objeciones de los Estados miembros y de los representantes de los empleadores, el Comité incorporó el precepto que excluye del Convenio el derecho a la autodeterminación de los pueblos, tal como es concebido en el derecho internacional (art. 1.3 del Convenio). De la misma manera, temiéndose que el concepto de "territorios" empleado en la propuesta del Secretariado pudiera interpretarse como atentatorio contra la soberanía nacional de los Estados, se introdujo la expresión "tierras o territorios" (art. 13 del Convenio). Por último, se rechazó la obligación de buscar el "consentimiento" de los pueblos indígenas para la aprobación de las medidas que los pudieran afectar, reemplazándose ese concepto por "consultas" (art. 6 del Convenio) $)^{30}$.

Junto con el cambio de paradigma recién descrito, la innovación más importante del nuevo texto consiste en la elevación de los estándares de protección. A saber, donde el Convenio 107 consagraba políticas

\footnotetext{
${ }^{28}$ Ibíd., pp. 274-280.

29 Ibíd., pp. 298-299.

${ }^{30}$ Ibíd., pp. 306-309.
} 
públicas recomendadas ${ }^{31}$, el Convenio 169 formula derechos. Asimismo, las cláusulas de flexibilidad, abundantes en el Convenio $107^{32}$, son excluidas por el Convenio 169, con lo que los derechos reconocidos por éste se conciben en términos absolutos, sin subordinarlos al derecho nacional ${ }^{33}$.

A pesar de lo controversial que había sido el proceso de su negociación, el Convenio 169 fue aprobado por un amplio margen de 328 votos a favor, con un solo voto en contra y con 49 abstenciones. Los representantes de los pueblos indígenas no tuvieron una participación directa en la negociación del Convenio, pues la estructura tripartita de la OIT únicamente dejaba espacio para su participación informal, pudiendo emitir sus observaciones a través de los representantes de los trabajadores. Aprobado el Convenio 169, las organizaciones indígenas expresaron un tajante repudio a sus términos ${ }^{34}$. Sin perjuicio de lo anterior, hubo una aceptación paulatina importante de las normas convencionales por parte de los Estados y de las organizaciones indígenas, lo que incluso ha llevado a algunos comentaristas a sostener que se trataría de una expresión del derecho consuetudinario internacional ${ }^{35}$.

${ }^{31}$ Véase, por ejemplo, el art. 2 del Convenio 107: "1. Incumbirá principalmente a los gobiernos desarrollar programas coordinados y sistemáticos con miras a la protección de las poblaciones en cuestión y a su integración progresiva en la vida de sus respectivos países. 2. Esos programas deberán comprender medidas: a) que permitan a dichas poblaciones beneficiarse, en pie de igualdad, de los derechos y oportunidades que la legislación nacional otorga a los demás elementos de la población; b) que promuevan el desarrollo social, económico y cultural de dichas poblaciones y el mejoramiento de su nivel de vida; c) que creen posibilidades de integración nacional, con exclusión de cualquier medida tendiente a la asimilación artificial de esas poblaciones".

32 Véase, por ejemplo, el art. 7.2. del Convenio 107: "Dichas poblaciones podrán mantener sus propias costumbres e instituciones cuando éstas no sean incompatibles con el ordenamiento jurídico nacional o los objetivos de los programas de integración", o el art. 8.1 del Convenio 107: "En la medida compatible con los intereses de la colectividad nacional y con el ordenamiento jurídico del país: a) los métodos de control social propios de las poblaciones en cuestión deberán ser utilizados, en todo lo posible, para la represión de los delitos cometidos por miembros de dichas poblaciones".

${ }^{33}$ Patrick Macklem, "Indigenous Recognition in International Law: Theoretical Observations", 2008, pp. 192-196.

${ }^{34}$ Chris Tennant, "Indigenous Peoples, International Institutions, and the International Legal Literature from 1945-1993”, 1994, p. 48.

35 James S. Anaya, Los Pueblos Indigenas en el Derecho Internacional, 2005, pp. 102 y ss. 


\subsection{Panorama general de la regulación internacional de los derechos indígenas}

Por último, cabe preguntarse por las alternativas al Convenio 169 de la OIT en el contexto del derecho internacional. En el seno de la ONU existe un importante rango de instrumentos internacionales que de manera tangencial atañen a los derechos indígenas, siendo los más relevantes la Declaración Universal de los Derechos Humanos, la Convención de la ONU para la Prevención y Sanción del Genocidio, ambos del año 1948; la Convención sobre la Eliminación de Todas las Formas de Discriminación Racial del año 1965; el Pacto Internacional de los Derechos Civiles y Políticos (en particular, su artículo 27\%); el Pacto Internacional de los Derechos Económicos, Sociales y Culturales del año 1966; y la Declaración de los Derechos de las Personas Pertenecientes a Minorías Nacionales o Étnicas, Religiosas y Lingüísticas del año $1992^{36}$. Los órganos de supervisión, establecidos de conformidad con algunos de esos instrumentos, han definido consistentemente los alcances de las normas en relación con los derechos indígenas, y han exigido a los Estados poner término a situaciones incompatibles con los estándares en ellos consagrados y adoptar acciones tendientes a superar distinciones entre los pueblos indígenas y no indígenas ${ }^{37}$.

En el ámbito interamericano destaca la Convención Interamericana de los Derechos Humanos (1969), que contempla un sistema jurisdiccional compuesto por la Comisión Interamericana de Derechos Humanos y la Corte Interamericana de Derechos Humanos. Dentro de las sentencias pronunciadas por la Corte en materia de derechos indígenas, el caso más emblemático corresponde al de la Comunidad Mayangna (Sumo) Awas Tingni vs. Nicaragua. En esa ocasión, la Corte reconoció el derecho colectivo a la tierra de una comunidad indígena de Nicaragua cuando el Estado había otorgado una concesión para la explotación forestal en sus tierras tradicionales en oposición de la comunidad nativa. La Corte interpretó el concepto de "propiedad" del artículo 21 de la Convención Interamericana sobre Derechos Humanos en forma evolutiva, incorporando en él las formas de tenencia colectiva de

${ }^{36}$ Rodolfo Stavenhagen, "Los Derechos Indígenas en el Sistema Internacional: Un Sujeto en Construcción”, 1998, pp. 83-91.

${ }^{37}$ Alexandra Xanthaki, "Indigenous Rights in International Law Over the Last 10 Years and Future Developments", 2009, pp. 27-28. 
la tierra ${ }^{38}$. El reconocimiento de los derechos colectivos de los pueblos indígenas sobre las tierras tradicionalmente ocupadas fue consolidado por la Corte Interamericana a través de una serie de fallos posteriores, en algunos de los cuales el respectivo precepto fue interpretado a la luz de lo establecido en el Convenio $169^{39}$.

Junto con lo anterior, el hito más relevante en el contexto de la regulación internacional de los derechos indígenas lo constituye, sin duda, la aprobación de la Declaración de las Naciones Unidas sobre los derechos de los pueblos indígenas, adoptada por Resolución de la Asamblea General con fecha 13 de septiembre de 2007. La preparación de este instrumento se había extendido por 25 años, proceso que transcurrió en un ambiente altamente controvertido, pero caracterizado por una permanente participación y colaboración de los representantes de los pueblos indígenas ${ }^{40}$. La Declaración irrumpe en el derecho internacional con el reconocimiento del derecho a la libre determinación, junto con establecer a través del artículo $46^{\circ}$ una limitación a cualquier interpretación que pueda "quebrantar o menoscabar, total o parcialmente, la integridad territorial o la unidad política de Estados soberanos e independientes" ${ }^{\prime 4}$.

La Declaración fue aprobada con los votos en contra de cuatro países con importantes porcentajes de población indígena: Canadá, Nueva Zelanda, EE. UU. y Australia, ninguno de los cuales ha ratificado el Convenio 169 de la OIT. Al explicitar su rechazo a la Declaración, el representante de Canadá señaló que las disposiciones de ésta relativas a los territorios y recursos naturales eran "excesivamente amplias, poco claras y susceptibles de una variedad de interpretaciones", que desconocían los títulos legítimos de propiedad que pudieran existir, al igual que podrían contrariar lo pactado en los tratados celebrados por ese país. Las disposiciones acerca del consentimiento libre, previo e informado de los pueblos indígenas frente a las iniciativas legislativas y adminis-

38 James S. Anaya, Los Pueblos Indígenas en el Derecho Internacional, 2005, pp. 361-371.

39 Mauricio Iván Del Toro Huerta, "The Contributions of the Jurisprudence of the Inter-American Court of Human Rights to the Configuration of Collective Property Rights of Indigenous Peoples", pp. 8-22, www.law.yale.edu/documents/pdf/sela/ Del_Toro.pdf.

${ }^{40}$ Megan Davis, "Indigenous Struggles in Standard-Setting: The United Nations Declaration on the Rights of Indigenous Peoples", pp. 442-458.

${ }^{41}$ Ibíd., pp. 461-462. 
trativas fueron consideradas excesivamente onerosas ${ }^{42}$. En el mismo sentido iba la posición de Nueva Zelanda, acorde a la cual, las normas de la Declaración creaban dos clases de ciudadanos, establecían discriminación en contra de aquellos no indígenas y no reflejaban la práctica contemporánea de los Estados. La Declaración no podría ser aceptada por un Estado que tomara en serio sus compromisos internacionales ${ }^{43}$. Semejantes objeciones fueron planteadas por EE. UU., que además alegó que la regulación del derecho a la libre determinación estaba fuera de los márgenes del mandato del Grupo de Trabajo, el que únicamente estaba facultado para abordar la noción de autogobierno. Asimismo, ese país criticó la figura jurídica de derechos colectivos como incompatible con el concepto de los derechos humanos ${ }^{44}$. Por su parte, con el cambio de gobierno en Australia, este país finalmente optó por apoyar la Declaración ${ }^{45}$.

La postura reticente de esos Estados a las iniciativas internacionales por regular los derechos indígenas no constituye necesariamente una negación de los mismos en el contexto de los ordenamientos jurídicos nacionales. Al contrario, todos ellos - con un grado diferente de intensidad y con fundamentos teóricos distintos - han adoptado una serie de regulaciones, decisiones judiciales y acuerdos reparatorios ${ }^{46}$. Ellos han llegado a ser descritos como overcompliant states, esto es,

${ }^{42}$ John McNee, Embajador de Canadá en la $61^{\text {a }}$ Asamblea General de la ONU, 13 de septiembre de 2007, http://www.canadainternational.gc.ca/prmny-mponu/canada un-canada_onu/statements-declarations/general_assembly-assemblee-generale/10373. aspx?lang=eng.

${ }^{43}$ Rosemary Banks, Representatne Permanente de Nueva Zelanda en la $61^{\text {a }}$ Asamblea General de la ONU, 13 de septiembre de 2007, http://www.nzembassy. $\mathrm{com} / \mathrm{info} . \mathrm{cfm}$ ?CFID $=7908039 \& \mathrm{CFTOKEN}=28311805 \& \mathrm{c}=51 \& \mathrm{l}=124 \& \mathrm{~s}=$ to $\& \mathrm{p}=63315$.

${ }^{44}$ EE. UU., Observaciones de EE. UU. con respecto a la Declaracion sobre los Derechos de los Pueblos Indígenas, 13 de septiebre de 2007, http://www.shunpiking. com/ol0406/0406-IP-positionofUS.htm.

${ }^{45}$ United Nations Radio, 3 de abril de 2009, http://www.unmultimedia.org/radio/ english/detail/72349.html.

${ }^{46}$ Sobre las numerosas iniciativas de reconciliación racial y protección de los derechos de los indígenas en esos países, véanse Sheryl R. Lightfoot, "Indigenous Rights in International Politics: The Case of 'Overcompliant' Liberal States", pp. 83-104; John Borrows, "Ground-Rules: Indigenous Treaties in Canada and New Zealand", 2006, pp. 188-212; Keith Barber, 'Indigenous Rights' or 'Racial Privileges': The Rhetoric of 'Race' in New Zealand Politics", 2008, pp. 141-156; Shin Imai, “Indigenous Self-Determination and the State", 2008, pp. 1-40. 
Estados que observan determinados criterios en materia de derechos indígenas sin aceptar la supremacía de las normas internacionales sobre el particular ${ }^{47}$.

Las poblaciones indígenas en esos países mantienen el estatus de minoría étnica, pero conviven en el contexto de una sociedad multicultural. En otras palabras, su porcentaje es relativamente bajo y cercano a $1,5 \%$ de la población total en EE. UU., a más de $2 \%$ en Australia y a más de $4 \%$ en Canadá, y rodea el $15 \%$ en Nueva Zelanda ${ }^{48}$. La reticencia a la normativa internacional tendría una explicación en la génesis misma de aquellos Estados. Las constituciones que los rigen se basan en ideas del liberalismo, individualismo, equidad y multiculturalismo, lo que restringe la posibilidad de establecer con los pueblos indígenas una especie de relación "entre naciones". Si bien existe una importante tendencia favorable al reconocimiento de los derechos humanos y la aspiración de desprenderse del pasado colonial, lo anterior limita la posibilidad de incorporar el reconocimiento de los derechos indígenas tal como ha sido forjado por las instituciones internacionales en su discurso $^{49}$.

En síntesis, la Declaración incorpora algunos derechos que claramente no son reconocidos aún como parte del derecho internacional. Sin embargo, debido al carácter no vinculante de la Declaración (soft law), a lo que se suma el rechazo que ha suscitado entre importantes actores del derecho internacional y la aparente falta de intención de otros países de transformarla en norma vinculante en el plano nacional, sería prematuro considerar que la Declaración es expresión del derecho consuetudinario internacional para estos efectos ${ }^{50}$. Con ello, es dudoso que esta Declaración pudiera dar inicio de inmediato a un proceso de generación de una normativa que con el tiempo se transforme en un instrumento internacional

${ }^{47}$ Sheryl R. Lightfoot, "Indigenous Rights in International Politics: The Case of 'Overcompliant' Liberal States”, 2008, p. 85.

48 Stephen Cornell, "Indigenous Peoples, Poverty and Self-Determination in Australia, New Zealand, Canada and the United States", 2006, pp. 3-6.

${ }^{49}$ Sheryl R. Lightfoot, "Indigenous Rights in International Politics: The Case of 'Overcompliant” Liberal States', 2008, p. 91.

${ }^{50}$ Alexandra Xanthaki, "Indigenous Rights in International Law Over the Last 10 Years and Future Developments", 2009, p. 36; Megan Davis, "Indigenous Struggles in Standard-Setting: The United Nations Declaration on the Rights of Indigenous Peoples", 2008, pp. 465-466. 
de carácter vinculante ${ }^{51}$. En ese escenario, el Convenio 169 de la OIT constituye el único instrumento internacional vinculante que de manera específica regula los derechos de los pueblos indígenas y tribales.

\subsection{La ratificación del Convenio 169 por Chile}

$\mathrm{Al}$ realizarse la votación del Convenio 169 en la OIT en el año 1989, Chile optó por la abstención. Luego, en 1991, el Convenio fue ingresado al Congreso Nacional y el 11 de abril de 2000 fue aprobado con una votación transversal mayoritaria por la Cámara de Diputados. Y, después de 17 años de trámite parlamentario, fue aprobado por el Senado el 4 de marzo de 2008 por 36 votos a favor y uno en contra. Chile ratificó el Convenio ante la OIT el 15 de septiembre de 2008, y el Convenio entró en vigor un año más tarde.

En dos ocasiones el Convenio 169 fue objeto de análisis por parte del Tribunal Constitucional chileno. La primera vez por un reclamo que planteaba que el Convenio era inconstitucional en su totalidad por contravenir las Bases de la Institucionalidad debido al uso del vocablo "pueblos indígenas" a quienes se les estarían transfiriendo funciones de ejercicio de soberanía radicadas en el pueblo de Chile ${ }^{52}$. El Tribunal rechazó este planteamiento dado que arribó a la conclusión de "que la expresión 'pueblos indígenas', debe ser considerada en el ámbito de dicho tratado, como un conjunto de personas o grupos de personas de un país que poseen en común características culturales propias, que no se encuentran dotadas de potestades públicas y que tienen y tendrán derecho a participar y a ser consultadas, en materias que les conciernan, con estricta sujeción a la Ley Suprema del respectivo Estado de cuya población forman parte. Ellos no constituyen un ente colectivo autónomo entre los individuos y el Estado" (Considerando 44). Asimismo, el Tribunal confirmó la constitucionalidad de una serie de disposiciones del Convenio, dentro de las cuales destacan aquellas relativas a la aplicación del derecho penal con relación a los miembros de los pueblos in-

${ }^{51}$ José Zalaquett, "La Declaración de Naciones Unidas sobre Derechos de los Pueblos Indígenas”, 2008, p. 140.

52 Tribunal Constitucional, Rol No 309, Requerimiento formulado por diversos diputados para que el tribunal resuelva la constitucionalidad del Convenio $\mathrm{N}^{\circ} 169$, de acuerdo al artículo 82, № 2, de la Constitución Política de la República, 4 de agosto de 2000. 
dígenas, a la aplicabilidad del derecho consuetudinario indígena, como también los artículos sobre las tierras y los recursos naturales.

El segundo control de constitucionalidad se efectuó a iniciativa de la Cámara de Diputados y apuntaba al análisis de las normas sobre la obligación del Estado de efectuar consultas con los pueblos indígenas en relación con aquellas medidas que los pudiesen afectar. El Tribunal Constitucional confirmó la constitucionalidad de los preceptos cuestionados y concluyó que "la consulta a los pueblos interesados que dispone el $\mathrm{N}^{\circ} 1$ del artículo $6^{\circ}$ del Acuerdo remitido no podrá, desde luego, entenderse que implique el ejercicio de soberanía, pues ella, conforme al claro tenor de lo dispuesto en el artículo $5^{\circ}$ de la Carta Fundamental, reside esencialmente en la Nación y se ejerce por el pueblo a través del plebiscito y de elecciones periódicas y, también, por las autoridades que la propia Constitución establece" (Considerando 13) ${ }^{53}$.

La discusión en el Congreso sobre los preceptos del Convenio 169 no fue más exhaustiva que la que aparece en los mismos informes de la OIT. Como se verá a través de lo expuesto en la sección 2 de este trabajo, los órganos de la OIT han formulado exigencias de alto nivel, las que se plantean ante los gobiernos de los países signatarios del Convenio 169 en relación con las medidas tomadas para su implementación.

\section{LAS DISPOSICIONES DEL CONVENIO 169 SEGÚN LA INTERPRETACIÓN DE LA OIT}

El Convenio 169 sobre pueblos indígenas y tribales en países independientes consiste de 44 artículos, agrupados en diez partes: I. Política general; II. Tierras; III. Contratación y condiciones de empleo; IV. Formación profesional, artesanía e industrias rurales; V. Seguridad social y salud; VI. Educación y medios de comunicación; VII. Contactos y cooperación a través de las fronteras; VIII. Administración; IX. Disposiciones generales; X. Disposiciones finales. La principal obligación de implementación que establece el Convenio 169 tiene como destinatarios a los gobiernos de los países firmantes. Así, el artículo 2 del Convenio señala que "los gobiernos deberán asumir la responsabili-

${ }^{53}$ Tribunal Constitucional, Rol No 1050, 3 de abril de 2008. 
dad de desarrollar, con la participación de los pueblos interesados, una acción coordinada y sistemática con miras a proteger los derechos de esos pueblos y a garantizar el respeto de su integridad".

Para respetar los límites a la extensión de esta investigación, esta sección se centra en algunas de sus normas más polémicas y que más frecuentemente han provocado pronunciamientos de los órganos de la OIT, siendo ello una señal de que se trata de disposiciones más sensibles y, por tanto, más relevantes para las políticas públicas. Esta segunda parte se inicia con un esbozo del sistema de la OIT para la supervisión del cumplimiento de los convenios ratificados por los Estados miembros (2.1). A continuación se analizan los preceptos relativos al ámbito de aplicación del Convenio 169 definido a través del concepto de "pueblos indígenas" (2.2), a la participación de los pueblos indígenas en las políticas públicas mediante consultas (2.3), y a los derechos sobre las tierras y recursos naturales (2.4).

\subsection{Principales características de la OIT}

La forma en que la OIT supervisa la implementación de los compromisos asumidos por los Estados miembros consiste en el monitoreo de los informes gubernamentales, solicitudes de información y pronunciamiento de sus órganos acerca de la compatibilidad entre las políticas estatales y las normas convencionales. Pero la organización no constituye un foro jurisdiccional y no dicta fallos ejecutables en contra de los Estados miembros. Los pronunciamientos que se emiten adoptan el lenguaje de evaluación: "toma nota con interés", "acoge con agrado", "lamenta tomar nota", "manifiesta su profunda preocupación", "solicita", "insta" o "requiere información", "solicita se garantice la observación de ciertos derechos", "alienta a seguir con esfuerzos", "se ve obligado a reiterar", etc. ${ }^{54}$. En ese sentido, el sistema carece de sanciones por la inobservancia de sus normas, siendo su forma de regular la conducta de los Estados netamente discursiva y persuasiva ${ }^{55}$.

${ }^{54}$ Véase, a modo de ejemplo, el Comisión de Expertos en Aplicación de Convenios y Recomendaciones, Informe General y observaciones referidas a ciertos países, Conferencia Internacional de Trabajo, 99 $9^{\mathrm{a}}$ reunión, 2010.

${ }^{55}$ Edward Weisband, "Discursive Multilateralism: Global Benchmarks, Shame, and Learning in the ILO Labor Standards Monitoring Regime", 2000, pp. 653-654. 
Los miembros de la OIT deben presentar a la Oficina Internacional del Trabajo una memoria anual sobre las medidas adoptadas para implementar los convenios ratificados, las que son puestas al conocimiento general en la siguiente reunión de la Conferencia (arts. 22-23 de la Constitución de la OIT). Ante el crecimiento del número de convenios ratificados y de memorias presentadas, en el año 1926 fue creada la Comisión de Expertos en Aplicación de Convenios y Recomendaciones $(\mathrm{CEACR})^{56}$, que cumple la función de evaluar, con criterios técnicos e imparciales, el estado de la aplicación de las normas internacionales del trabajo. Actualmente, la Comisión está compuesta por 20 juristas, nombrados por el Consejo de Administración de la OIT por períodos de tres años. La CEACR efectúa dos tipos de comentarios en relación con las memorias recibidas: observaciones y solicitudes directas. Las observaciones contienen comentarios sobre las cuestiones fundamentales planteadas por la aplicación de un determinado convenio por parte de un Estado. Estas observaciones se publican en el informe anual de la Comisión. Las solicitudes directas se relacionan con cuestiones más técnicas o con peticiones de más información; no se publican en el informe sino que se comunican directamente a los gobiernos concernidos ${ }^{57}$.

El informe anual de CEACR es presentado a la Conferencia Internacional del Trabajo, donde es examinado por la Comisión de Aplicación de Normas de la Conferencia. Esta Comisión, que es permanente, está compuesta por delegados de los gobiernos, de los empleadores y de los trabajadores. Ella analiza el informe en un marco tripartito y selecciona del mismo diversos comentarios que serán objeto de debate. Los gobiernos mencionados en estos comentarios son invitados a responder ante la Comisión de la Conferencia y a informar sobre la situación en consideración. En muchos casos, la Comisión de la Conferencia adopta conclusiones, recomendando a los gobiernos que arbitren medidas específicas para solucionar un problema o que soliciten asistencia técnica a la OIT $^{58}$.

${ }^{56}$ Laurence R. Helfer, "Understanding Change in International Organizations: Globalization and Innovation in the ILO”, 2006, pp. 686-688.

57 Organización Internacional del Trabajo (OIT), http://www.ilo.org/global/ What_we_do/InternationalLabourStandards/ApplyingandpromotingInternationalLabourStandards/CommitteeofExperts/lang--es/index.htm.

${ }^{58}$ Ibíd. 
La OIT contempla un sistema de reclamaciones individuales en contra de los Estados por supuesto incumplimiento de los compromisos contraídos, las que pueden ser presentadas por una organización profesional de empleadores o de trabajadores (art. 24). El estudio de cada caso se desarrolla a puertas cerradas, a menos que el Consejo de Administración no reciba en un plazo razonable declaración alguna del gobierno, o en caso que la declaración recibida se considerare insatisfactoria (art. 25). Asimismo, se establece un procedimiento de queja (arts. 26-34), que los Estados miembros, un delegado a la Conferencia Internacional o el Consejo de Administración en el marco de sus competencias pueden iniciar contra los demás miembros de la OIT. Para tratar la materia se constituye una comisión de encuesta, compuesta por tres miembros independientes. El gobierno afectado puede aceptar recomendaciones contenidas en el informe de la comisión, y en caso contrario puede solicitar el inicio de un juicio ante la Corte Internacional de Justicia. En el evento que un Estado miembro no dé cumplimiento a las recomendaciones de la Comisión de Encuesta o a la decisión de la Corte Internacional de Justicia, el Consejo de Administración de la OIT podrá recomendar a la Conferencia las medidas que estime convenientes para obtener el cumplimiento de dichas recomendaciones (art. 33). Durante la historia de la Organización, el procedimiento de queja ha sido iniciado 35 veces y la Comisión de Encuesta ha sido convocada 11 veces; en su mayoría, las remisiones fueron hechas por los delegados de la Conferencia ${ }^{59}$. La aplicación de sanciones en ese contexto se había anunciado en contra del Estado de Myanmar, a raíz de la situación de ese país en materia de trabajo forzoso. Sin embargo, las sanciones anunciadas por los EE. UU. fueron suspendidas a la brevedad ${ }^{60}$.

\section{2. Ámbito de aplicación del Convenio 169 a la luz del concepto de "pueblos indígenas"}

Según lo señalado precedentemente, el art. 1.3 del Convenio 169 descarta que la aplicación del término "pueblos" en este Convenio pudiera "interpretarse en el sentido de que tenga implicación alguna en

\footnotetext{
${ }^{59}$ Organización Internacional del Trabajo (OIT), http://www.ilo.org/ilolex.

${ }^{60}$ Michael Ewing-Chow, "First Don No Harm: Myanmar Trade Sanctions and Human Rights”, 2007, pp. 153-180.
} 
lo que atañe a los derechos que pueda conferirse a dicho término en el derecho internacional". Por lo anterior, estamos ante un término funcional, cuyos alcances se establecen a través de las nociones propias del Convenio mismo. Definir la cobertura del Convenio 169 resulta crucial para su aplicación correcta, pero tal definición debe hacerse de conformidad con lo que exija este instrumento internacional. Así, por ejemplo, frente al planteamiento del gobierno de Guatemala que las políticas públicas del país se implementaban sin hacer distinción étnica, la Comisión sostuvo que "el Convenio prevé la implementación de una serie de políticas públicas dirigidas exclusivamente a los pueblos indígenas y que en ello radica la importancia de definir los criterios que determinan su campo de aplicación personal. La Comisión confía que el Gobierno hará lo posible para fijar, en consulta con los pueblos interesados, criterios para identificar a las poblaciones susceptibles de ser cubiertas por el Convenio, teniendo en cuenta que, al efecto, el párrafo 2 de este artículo establece que la conciencia de su identidad indígena deberá considerarse un criterio fundamental." 61.

El Convenio 169 se aplica a pueblos indígenas y tribales, y dada la dificultad de contar con una definición exacta de los mismos, combina elementos objetivos, relativos a características socioculturales y procedencia histórica de los referidos pueblos (art. 1.1 $)^{62}$, con el elemento subjetivo de la autoidentificación de los individuos como pertenecientes a los pueblos indígenas y tribales (art. 1.2) ${ }^{63}$. La CEACR ha sido enfática en solicitar a los Estados que incorporen el criterio de autoidentificación de los miembros de los pueblos indígenas en las legislaciones

${ }^{61}$ Comisión de Expertos en Aplicación de Convenios y Recomendaciones, Solicitud directa individual sobre el Convenio sobre pueblos indígenas y tribales, Guatemala, 2007, pár. 1 .

${ }^{62}$ Acorde al artículo $1^{\circ}$ del Convenio 169 , éste se aplica: “a) a los pueblos tribales en países independientes, cuyas condiciones sociales, culturales y económicas les distingan de otros sectores de la colectividad nacional, y que estén regidos total o parcialmente por sus propias costumbres o tradiciones o por una legislación especial; b) a los pueblos en países independientes, considerados indígenas por el hecho de descender de poblaciones que habitaban en el país o en una región geográfica a la que pertenece el país en la época de la conquista o la colonización o del establecimiento de las actuales fronteras estatales y que, cualquiera que sea su situación jurídica, conservan todas sus propias instituciones sociales, económicas, culturales y políticas, o parte de ellas".

${ }^{63}$ Art. 1.2 del Convenio 169: "La conciencia de su identidad indígena o tribal deberá considerarse un criterio fundamental para determinar los grupos a los que se aplican las disposiciones del presente Convenio". 
nacionales ${ }^{64}$ : "La conciencia de su identidad indígena o tribal deberá considerarse un criterio fundamental para determinar los grupos a los que se aplican las disposiciones del Convenio", siendo deseable que dicho criterio sea incorporado en los censos de la población y que cuente con "expresión legislativa en consulta con los pueblos indígenas"65.

Los criterios adicionales que contenga la legislación interna para definir la pertenencia de una persona a un pueblo indígena, no pueden tener como efecto alterar el ámbito de aplicación del Convenio. Así, por ejemplo, la ley mexicana, junto con usar el criterio de autodefinición, emplea el elemento de asentamiento físico de los integrantes de un pueblo indígena en un territorio. Sin embargo, el Convenio exige también "el reconocimiento de la condición de miembros de aquellos pueblos o comunidades indígenas que hayan perdido sus tierras ancestrales o se han reasentado en zonas urbanas" $" 66$.

De la misma manera, las formalidades que pudiera establecer la ley interna del país como requisito de reconocimiento de una comunidad indígena no pueden restringir el goce de los derechos del Convenio. Se alegaba que en Argentina, de las 850 comunidades indígenas sólo el 15 por ciento estarían reconocidas ante el Instituto Nacional del Indígena (INAI), lo que les impedía defender sus derechos en tribunales o ante la administración pública. Si bien el gobierno de Argentina argumentaba que la personería jurídica de las comunidades indígenas se inscribía respetando las costumbres y formas de organización propias y firmando convenios sobre esta cuestión con las provincias, la Comisión invitó al gobierno de Argentina a asegurar que el trámite de inscripción tenga un carácter declarativo y no constitutivo ${ }^{67}$.

${ }^{64}$ Por ejemplo, Comisión de Expertos en Aplicación de Convenios y Recomendaciones, Solicitud directa individual sobre el Convenio sobre pueblos indígenas y tribales, Perú, 1999, par. 2.

${ }^{65}$ Comisión de Expertos en Aplicación de Convenios y Recomendaciones, Solicitud directa individual sobre el Convenio sobre pueblos indígenas y tribales, Paraguay, 2007, par. 1 .

${ }^{66}$ Comisión de Expertos en Aplicación de Convenios y Recomendaciones, Solicitud directa individual sobre el Convenio sobre pueblos indígenas y tribales, México, 2002, par. 5 .

${ }^{67}$ Comisión de Expertos en Aplicación de Convenios y Recomendaciones, Solicitud directa individual sobre el Convenio sobre pueblos indígenas y tribales, Argentina, 2007, pár. 3. 


\subsection{Derecho a la participación en políticas públicas y autodeterminación de los pueblos indígenas}

El espíritu de consulta y de participación, establecidos en los artículos $6^{68}$ y $7^{69}$, constituyen la piedra angular del Convenio 169, en la que se fundamentan todas las disposiciones del mismo ${ }^{70}$. La consulta es el instrumento previsto por el Convenio para institucionalizar el diálogo, asegurar procesos de desarrollo incluyentes y prevenir y resolver conflictos. La consulta en los términos previstos por el Convenio intenta armonizar intereses a veces contrapuestos mediante procedimientos adecuados ${ }^{71}$. Por lo tanto, se requiere entablar un procedimiento que genere las condiciones propicias para poder llegar a un acuerdo o lograr el consentimiento acerca de las medidas propuestas, independientemente del resultado alcanzado. Es decir, la expresión "procedimientos apropiados" debe entenderse con referencia a la finalidad de la consulta, que es la de llegar a un acuerdo o lograr el consentimiento. No es necesario, por supuesto, que un acuerdo se logre o que el consentimiento a la me-

68 Artículo 6 del Convenio 169: "1. Al aplicar las disposiciones del presente Convenio, los gobiernos deberán: a) consultar a los pueblos interesados, mediante procedimientos apropiados y en particular a través de sus instituciones representativas, cada vez que se prevean medidas legislativas o administrativas susceptibles de afectarles directamente; b) establecer los medios a través de los cuales los pueblos interesados puedan participar libremente, por lo menos en la misma medida que otros sectores de la población, y a todos los niveles en la adopción de decisiones en instituciones electivas y organismos administrativos y de otra índole responsables de políticas y programas que les conciernan; c) establecer los medios para el pleno desarrollo de las instituciones e iniciativas de esos pueblos, y en los casos apropiados proporcionar los recursos necesarios para este fin. 2. Las consultas llevadas a cabo en aplicación de este Convenio deberán efectuarse de buena fe y de una manera apropiada a las circunstancias, con la finalidad de llegar a un acuerdo o lograr el consentimiento acerca de las medidas propuestas".

${ }^{69}$ Artículo 7.1 del Convenio 169: "Los pueblos interesados deberán tener el derecho de decidir sus propias prioridades en lo que atañe al proceso de desarrollo, en la medida en que éste afecte a sus vidas, creencias, instituciones y bienestar espiritual y a las tierras que ocupan o utilizan de alguna manera, y de controlar, en la medida de lo posible, su propio desarrollo económico, social y cultural. Además, dichos pueblos deberán participar en la formulación, aplicación y evaluación de los planes y programas de desarrollo nacional y regional susceptibles de afectarles directamente."

${ }^{70}$ Comité establecido para examinar la reclamación en la que se alega el incumplimiento por Ecuador del Convenio sobre pueblos indígenas y tribales, presentada en virtud del artículo 24 de la Constitución de la OIT por la Confederación Ecuatoriana de Organizaciones Sindicales Libres (CEOSL), Informe, 2000, pár. 31 y 33.

${ }^{71}$ Comisión de Expertos en Aplicación de Convenios y Recomendaciones, Observación individual sobre el Convenio sobre pueblos indígenas y tribales, Guatemala, 2006, pár. 6 . 
dida en cuestión se obtenga ${ }^{72}$. Sin embargo, se debe garantizar que los pueblos interesados tengan la oportunidad de participar libremente en todos los niveles en la formulación, aplicación y evaluación de medidas y programas que les afecten directamente ${ }^{73}$.

En esta labor el Estado no puede asumir un rol pasivo alegando, por ejemplo, que "las comunidades indígenas, por su propio albedrío, desarrollan acciones de construcción social comunitaria y autodeterminación de los pueblos. [...] que el gobierno no participa en estos procesos y se limita a velar por su autodeterminación y el respeto de las costumbres, creencias y demás rasgos ancestrales de estas comunidades." Más aún, el gobierno tiene la obligación de proporcionar recursos necesarios para que esas comunidades puedan desarrollar sus propias instituciones e iniciativas ${ }^{74}$.

El artículo 6 del Convenio no establece exactamente el momento en que debe iniciarse la consulta, pero su espíritu indica que deben establecerse mecanismos que aseguren la consulta de las medidas legislativas y administrativas con la suficiente antelación para que dicha consulta resulte efectiva y significativa, esto es, las consultas deben emprenderse mientras los proyectos están aún en trámite ${ }^{75}$. Las normas del Convenio implican la obligación de desarrollar un proceso de consulta previa con los pueblos indígenas antes de tomar medidas susceptibles de afectarles directamente, tales como la firma de un contrato autorizando actividades relacionadas con la exploración o explotación de hidrocarburos en su territorio ancestral, o con la continuación de las ac-

${ }^{72}$ Comité encargado de examinar la reclamación en la que se alega el incumplimiento por Mexico del Convenio sobre pueblos indígenas y tribales, presentada en virtud del artículo 24 de la Constitución de la OIT por el Sindicato de Trabajadores de la Universidad Autónoma de México (STUNAM) y el Sindicato Independiente de Trabajadores de la Jornada (SITRAJOR), Informe, 2001, pár. 89.

${ }^{73}$ Comité establecido para examinar la reclamación en la que se alega el incumplimiento por Colombia del Convenio sobre pueblos indígenas y tribales, presentada en virtud del artículo 24 de la Constitución de la OIT por la Central Unitaria de Trabadores (CUT), Informe, 1999, pár. 78.

${ }^{74}$ Comisión de Expertos en Aplicación de Convenios y Recomendaciones, Solicitud directa individual sobre el Convenio sobre pueblos indígenas y tribales, Ecuador, 2004, pár. 5 .

${ }^{75}$ Comité encargado de examinar la reclamación en la que se alega el incumplimiento por Argentina del Convenio sobre pueblos indígenas y tribales, presentada en virtud del artículo 24 de la Constitución de la OIT por la Unión de Trabajadores de la Educación de Río Negro (Un.T.E.R), gremio de base de la Confederación de Trabajadores de la Educación de la República Argentina (C.T.E.R.A.), Informe, 2006, pár. 64. 
tividades iniciadas con anterioridad a la entrada en vigor del Convenio. Así, la obligación de consulta previa significa que se deberá consultar a los pueblos interesados antes de finalizar el estudio ambiental y el plan de gestión ambiental ${ }^{76}$. Una consulta tardía, cuando ya los planes para el desarrollo de la región están definidos sin la participación de los pueblos indígenas, sería ineficaz ${ }^{77}$. Una reunión de mera información no se puede considerar en conformidad con lo dispuesto en el Convenio ${ }^{78}$. Tampoco cumple con las exigencias del Convenio un procedimiento de consulta que se reduzca a una sola reunión en la que la medida proyectada y el estudio del impacto ambiental se relatan a la comunidad jurídica, sin contemplar su participación en la preparación y la formulación del plan de manejo ambiental ${ }^{79}$. Resulta insuficiente que durante el trámite legislativo las audiencias se realicen una sola vez con cada sector, persona u organización y no todas las personas u organizaciones tengan la oportunidad de ser oídas. Es necesario que se instaure un intercambio genuino con continuidad y tiempo para, al menos, tener la posibilidad de llegar a acuerdo ${ }^{80}$.

La necesidad de tomar decisiones expeditas no debe perjudicar la realización de una consulta efectiva, para la cual se han de prever los tiempos necesarios para que los pueblos indígenas del país puedan llevar a cabo sus procesos de toma de decisión y participar efectivamente en los acuerdos tomados de una manera que se adapte a sus modelos culturales y sociales. No se pretende sugerir que dichos modelos sean los únicos que pueden servir de base para un proceso de consulta en

${ }^{76}$ Comité establecido para examinar la reclamación en la que se alega el incumplimiento por Ecuador del Convenio sobre pueblos indígenas y tribales, presentada en virtud del artículo 24 de la Constitución de la OIT por la Confederación Ecuatoriana de Organizaciones Sindicales Libres (CEOSL), Informe, 2000, pár. 39.

${ }^{77}$ Comisión de Expertos en Aplicación de Convenios y Recomendaciones, Observación individual sobre el Convenio sobre pueblos indígenas y tribales, Guatemala, 2009, pár. "Participación y consulta".

${ }^{78}$ Comité establecido para examinar la reclamación en la que se alega el incumplimiento por Colombia del Convenio sobre pueblos indígenas y tribales, presentada en virtud del artículo 24 de la Constitución de la OIT por la Central Unitaria de Trabadores (CUT), Informe, 1999, pár. 90.

${ }^{79}$ Ibíd., pár. 75-76.

${ }^{80}$ Comité encargado de examinar la reclamación en la que se alega el incumplimiento por México del Convenio sobre pueblos indígenas y tribales, presentada en virtud del artículo 24 de la Constitución de la OIT por el Sindicato de Trabajadores de la Universidad Autónoma de México (STUNAM) y el Sindicato Independiente de Trabajadores de la Jornada (SITRAJOR), Informe, 2001, pár. 94. 
conformidad con el Convenio, pero si éstos no se tienen en cuenta, será imposible cumplir con los requisitos fundamentales de la consulta previa y la participación ${ }^{81}$.

El artículo 6 del Convenio requiere que la consulta sea previa, lo que implica que las comunidades afectadas participen lo antes posible en el proceso, incluso en la realización de estudios de impacto ambiental. En un caso que afectó a Ecuador, el proyecto cuestionado fue establecido antes de que el Convenio entrara en vigor en ese país. Sin embargo, en el momento en que entró en vigor surgió la obligación de la consulta relativa a toda actividad que afecte la aplicación del Convenio $^{82}$. De la misma manera, no importa si la medida (en otro caso, la construcción de una carretera en Colombia) es nueva o si únicamente busca modernizar una obra ya existente, los trabajos que se emprendan tienen que definirse en consulta con las comunidades por las cuales atraviesa la obra y teniendo en cuenta el interés y derechos de las mismas. En ambas situaciones resultan aplicables las disposiciones del Convenio en lo que se refiere a la consulta y participación ${ }^{83}$. Si bien el proyecto ya había sido aprobado antes de que el Convenio entrara en vigor en el país, las obras estaban en curso. Desde el momento en que el Convenio entró en vigor, el gobierno tenía la obligación de consultar con los pueblos interesados sobre la consecución de las obras ${ }^{84}$.

Otro elemento que los órganos de la OIT han subrayado enfáticamente es la necesidad de que la participación y la consulta con los pueblos indígenas se efectúe a través de sus propias instituciones repre-

${ }^{81}$ Comité establecido para examinar la reclamación en la que se alega el incumplimiento por Colombia del Convenio sobre pueblos indígenas y tribales, presentada en virtud del artículo 24 de la Constitución de la OIT por la Central Unitaria de Trabadores (CUT), Informe, 1999, pár. 79.

${ }^{82}$ Comité establecido para examinar la reclamación en la que se alega el incumplimiento por Ecuador del Convenio sobre pueblos indígenasy tribales, presentada en virtud del artículo 24 de la Constitución de la OIT por la Confederación Ecuatoriana de Organizaciones Sindicales Libres (CEOSL), Informe, 2000, par. 38.

${ }^{83}$ Comité encargado de examinar la reclamación en la que se alega el incumplimiento por México del Convenio sobre pueblos indígenas y tribales, presentada en virtud del artículo 24 de la Constitución de la OIT por el Sindicato de Trabajadores de la Industria Metálica, Acero, Hierro, Conexos y Similares (STIMAHCS), Informe, 2002, pár. 39.

${ }^{84}$ Comité establecido para examinar la reclamación en la que se alega el incumplimiento por Colombia del Convenio sobre pueblos indígenas y tribales, presentada en virtud del artículo 24 de la Constitución de la OIT por la Central Unitaria de Trabadores (CUT), Informe, 1999, par. 82 
sentativas. En este contexto el Comité de Expertos hizo observaciones sobre la situación en Venezuela respecto a la composición del Instituto a cargo de asuntos indígenas, el cual actuó como contraparte de la consulta. Mientras el presidente y el vicepresidente de la Junta Directiva del Instituto eran designados por el Presidente de la República previa propuesta de los pueblos indígenas, los demás miembros eran nombrados por el presidente del Instituto, con lo que no se garantizaba necesariamente la participación de los pueblos indígenas en este Instituto y su carácter representativo ${ }^{85}$.

El Convenio no determina que un solo organismo representativo pueda iniciar procedimientos de consulta, por lo que el Comité entiende que todo organismo representativo designado por los indígenas debería gozar de esta posibilidad ${ }^{86}$. Conforme con lo que establece el artículo $6,1, \mathrm{c})$, al aplicar las disposiciones del Convenio, los gobiernos deberán establecer los medios para el pleno desarrollo de las instituciones e iniciativas de esos pueblos, y en los casos apropiados proporcionar los recursos necesarios para este fin, dando soluciones financieras a las dificultades que pudiera enfrentar un órgano representativo de los pueblos indígenas por falta de presupuesto ${ }^{87}$.

El principio de representatividad constituye un componente esencial de las consultas. Aunque algunas veces resulta difícil determinar quién representa a una comunidad en particular, sin embargo, si no se desarrolla un proceso de consulta adecuado con las instituciones $\mathrm{u}$ organizaciones indígenas y tribales verdaderamente representativas de las comunidades afectadas, la consulta encaminada no cumplirá con los requisitos del Convenio ${ }^{88}$. No sería suficiente entablar un diálogo únicamente con las "organizaciones más representativas del movimiento

${ }^{85}$ Comisión de Expertos en Aplicación de Convenios y Recomendaciones, Solicitud directa individual sobre el Convenio sobre pueblos indígenas y tribales, República Bolivariana de Venezuela, 2008, par. 4.

${ }^{86}$ Comité encargado de examinar la reclamación en la que se alega el incumplimiento por Argentina del Convenio sobre pueblos indígenas y tribales, presentada en virtud del artículo 24 de la Constitución de la OIT por la Unión de Trabajadores de la Educación de Río Negro (Un.T.E.R), gremio de base de la Confederación de Trabajadores de la Educación de la República Argentina (C.T.E.R.A.), Informe, 2006, pár. 78.

${ }^{87}$ Comité establecido para examinar la reclamación en la que se alega el incumplimiento por Ecuador del Convenio sobre pueblos indígenas y tribales, presentada en virtud del artículo 24 de la Constitución de la OIT por la Confederación Ecuatoriana de Organizaciones Sindicales Libres (CEOSL), Informe, 2000, pár. 44.

${ }^{88}$ Ibíd. 
indígena", en tanto que el Convenio se refiere a las "instituciones representativas de los pueblos indígenas" $"$.

Frente al retiro voluntario de una organización indígena de la Coordinadora del Parlamento Mapuche de Argentina (con lo cual resultó autoexcluida de los mecanismos de representatividad), se estimó que dicha organización había renunciado a las posibilidades de participar en los órganos previstos por la normativa interna, pero eso no implicaba que, en la medida en que sea realmente representativa, haya perdido los derechos consagrados en el Convenio 169 y, en particular, el derecho de ser consultada y de participar en las cuestiones susceptibles de afectar directamente a las comunidades que representa. A juicio del Comité, "dada la diversidad de los pueblos indígenas, el Convenio no impone un modelo de institución representativa, lo importante es que ésta sea el fruto de un proceso propio, interno de los pueblos indígenas. Pero es fundamental cerciorarse de que la consulta se lleva a cabo con las instituciones realmente representativas de los pueblos interesados" $" 90$.

En síntesis, la consulta prevista por el artículo 6 del Convenio 169 comprende requisitos específicos. Para que un intercambio de información y opinión se considere de conformidad con los requisitos de este precepto, deberá ser efectuado de buena fe mediante procedimientos apropiados a las circunstancias y convocando para ello instituciones representativas de los pueblos indígenas. Será apropiado para tales fines el procedimiento que genere las condiciones propicias para poder llegar a un acuerdo o lograr el consentimiento acerca de las medidas propuestas. Es decir, la expresión "procedimientos apropiados" debe entenderse con referencia a la finalidad de la consulta. No hay un único modelo de procedimiento apropiado y éste debería tener en cuenta las circunstancias nacionales y de los pueblos indígenas afectados, así como la naturaleza de las medidas consultadas. En cuanto al propio proceso

${ }^{89}$ Comité encargado de examinar la reclamación en la que se alega el incumplimiento por Mexico del Convenio sobre pueblos indígenas y tribales, presentada en virtud del artículo 24 de la Constitución de la OIT por el Sindicato de Trabajadores de la Universidad Autónoma de México (STUNAM) y el Sindicato Independiente de Trabajadores de la Jornada (SITRAJOR), Informe, 2001, pár. 101.

${ }^{90}$ Comité encargado de examinar la reclamación en la que se alega el incumplimiento por Argentina del Convenio sobre pueblos indígenas y tribales, presentada en virtud del artículo 24 de la Constitución de la OIT por la Unión de Trabajadores de la Educación de Río Negro (Un.T.E.R), gremio de base de la Confederación de Trabajadores de la Educación de la República Argentina (C.T.E.R.A.), Informe, 2006, pár. 74 y 75. 
de consulta, éste debería tomar en cuenta la opinión de los diferentes pueblos que participan en la consulta sobre el procedimiento a utilizarse para el intercambio, de manera que el procedimiento utilizado sea considerado apropiado por todas las partes. La validez de los procesos de consulta previstos por el Convenio como mecanismo para prevenir y resolver conflictos depende de la construcción de mecanismos de diálogo fecundos. La consulta prevista por el Convenio no es por lo tanto un requisito formal, sino un verdadero instrumento de participación ${ }^{91}$.

\subsection{Los derechos sobre las tierras y recursos naturales}

El artículo 14 del Convenio introduce, primero, la obligación de reconocer a los pueblos indígenas "el derecho de propiedad y de posesión sobre las tierras que tradicionalmente ocupan". En segundo lugar, contempla la obligación de tomar medidas para garantizarles la posibilidad de utilizar "tierras que no estén exclusivamente ocupadas por ellos, pero a las que hayan tenido tradicionalmente acceso para sus actividades tradicionales y de subsistencia". Acorde con el inciso $2^{\circ}$ del artículo 14, deberían tomarse "medidas que sean necesarias para determinar las tierras que los pueblos interesados ocupan tradicionalmente y garantizar la protección efectiva de sus derechos de propiedad y posesión". La aplicación práctica del artículo 14 ha sido observada por los distintos órganos de la OIT. Sus informes reflejan una importante discrepancia entre las expectativas de la Organización y la interpretación realizada por los gobiernos locales.

A juicio del CEACR, el artículo 14 del Convenio prevé que los gobiernos deberán tomar las medidas que sean necesarias para garantizar la protección efectiva de los derechos de propiedad y posesión de los pueblos indígenas, y deben brindar la posibilidad real para que éstos puedan solucionar sus reivindicaciones de tierras. Esto significa también que los gobiernos deben tomar los pasos necesarios para identificar las tierras que han sido tradicionalmente ocupadas por estos pueblos y garantizar una protección efectiva de los derechos de propiedad y posesión. El gobierno debería poder dar cuenta de cómo funciona en la prác-

${ }^{91}$ Comité encargado de examinar la reclamación en la que se alega el incumplimiento por Brasil del Convenio sobre pueblos indígenas y tribales, presentada en virtud del artículo 24 de la Constitución de la OIT por el Sindicato de Ingenieros del Distrito Federal (SENGE/DF), Informe, 2006, pár. 42. 
tica el proyecto especial de titulación de tierras y catastro rural, cuántas tierras han sido tituladas a pueblos indígenas y cuántas a personas no indígenas, cuál es el costo monetario del procedimiento, si es que existe, y finalmente cuáles son los requisitos a seguir para obtener la titulación y los textos legales que rigen tal procedimiento ${ }^{92}$.

De conformidad con el artículo 14 del Convenio, "el gobierno debería desplegar esfuerzos para acelerar los procesos de regularización de las tierras que las comunidades indígenas ocupan tradicionalmente y asegurándose no sólo de garantizar sus derechos individuales sino también sus derechos colectivos y los diferentes aspectos de su relación con la tierra. En efecto, los derechos sobre las tierras ocupadas tradicionalmente y reconocidos por el Convenio no tienden solamente a preservar la propiedad y posesión sino también la propia sobrevida de los pueblos indígenas como tales y su continuidad histórica"93. En virtud del Convenio, el gobierno tiene la obligación de, por ejemplo, prevenir e impedir la pérdida continua de tierras indígenas, especialmente cuando es el resultado de "despojo" por parte de particulares o de demoras en los procedimientos judiciales. También tiene la obligación de garantizar que el marco legislativo, administrativo y judicial adoptado para implementar las reformas constitucionales no disminuya el grado de protección ${ }^{94}$. La experiencia de la OIT muestra que cuando las tierras indígenas de tenencia común se dividen o asignan a particulares o terceros, el ejercicio de los derechos de las comunidades indígenas tiende a debilitarse y, por lo general, acaban perdiendo todas las tierras o parte de ellas. Aunque no está entre las funciones de la OIT la de determinar si la propiedad colectiva o individual era la más apropiada para los pueblos indígenas o tribales en una situación determinada, la Conferencia había decidido, cuando adoptó el Convenio, que involucrar

${ }^{92}$ Comisión de Expertos en Aplicación de Convenios y Recomendaciones, Solicitud directa individual sobre el Convenio sobre pueblos indígenas y tribales, Perú, 1999, pár. 14.

${ }^{93}$ Comité encargado de examinar la reclamación en la que se alega el incumplimiento por Guatemala del Convenio sobre pueblos indígenas y tribales, presentada en virtud del artículo 24 de la Constitución de la OIT por la Federación de Trabajadores del Campo y la Ciudad (FTCC), Informe, 2005, pár. 44.

${ }^{94}$ Comité encargado de examinar la reclamación en la que se alega el incumplimiento por Mexico del Convenio sobre pueblos indígenas y tribales, presentada en virtud del artículo 24 de la Constitución de la OIT por el Sindicato de Trabajadores de la Universidad Autónoma de México (STUNAM) y el Sindicato Independiente de Trabajadores de la Jornada (SITRAJOR), Informe, 2001, pár. 138. 
a estos pueblos en la decisión sobre la forma de propiedad de la tierra era de extrema importancia ${ }^{95}$.

Se reconoce que la regularización de las tierras requiere tiempo y que no basta con la adopción de legislación, sino que es el resultado de un proceso complejo. No obstante, los pueblos indígenas no deben resultar perjudicados por la duración de dicho proceso. En consecuencia, sería deseable que se adoptaran medidas transitorias para proteger los derechos sobre las tierras de los pueblos interesados. La opinión vertida por el gobierno de Guatemala, en el sentido de que la tenencia de las tierras que las comunidades indígenas ocupan tradicionalmente era ilegal al no tener título de propiedad, iba en contra del Convenio cuyo artículo 14 reconoce los derechos de los pueblos indígenas sobre las tierras que ocupan tradicionalmente ${ }^{96}$. El Comité reconoce que existen dificultades para conciliar los derechos consagrados por el Convenio en materia de tierras con las disposiciones de los Códigos Civiles y otras derivadas del mismo. Sin embargo, se requiere la plena aplicación de estos artículos y entre ellos la institución de procedimientos adecuados en el marco del sistema jurídico nacional para solucionar las reivindicaciones de tierras ${ }^{97}$.

En el caso de Costa Rica se informó que existían grandes áreas de tierras indígenas en manos de no indígenas y que el gobierno no contaba con los fondos suficientes para compensar a esas personas. Frente a ello, "la Comisión solicitó al Gobierno que le informe cómo intenta aplicar la ley indígena en lo referente al desalojo de estas personas, así como con qué otros medios legales se cuenta para accionar la devolución de tierras a sus propietarios ancestrales. Igualmente solicita al Gobierno que le informe si existen procedimientos adecuados dentro del sistema jurídico nacional disponibles para que los pueblos indígenas

${ }^{95}$ Comisión de Expertos en Aplicación de Convenios y Recomendaciones, Observación individual sobre el Convenio sobre pueblos indígenas y tribales, Perú, 1999, pár. 5.

${ }^{96}$ Informe del Comité encargado de examinar la reclamación en la que se alega el incumplimiento por Guatemala del Convenio sobre pueblos indígenas y tribales, presentada en virtud del artículo 24 de la Constitución de la OIT por la Federación de Trabajadores del Campo y la Ciudad (FTCC), Informe, 2005, pár. 45.

${ }^{97}$ Comité encargado de examinar la reclamación en la que se alega el incumplimiento por Mexico del Convenio sobre pueblos indígenas y tribales, presentada en virtud del artículo 24 de la Constitución de la OIT por el Sindicato de Trabajadores de la Universidad Autónoma de México (STUNAM) y el Sindicato Independiente de Trabajadores de la Jornada (SITRAJOR), Informe, 2001, pár. 134. 
puedan ejercer el derecho a reivindicar áreas que hayan sido usurpadas o no delimitadas"98.

Por su parte, el párrafo $1^{\circ}$ del artículo 15 del Convenio señala: "Los derechos de los pueblos interesados a los recursos naturales existentes en sus tierras deberán protegerse especialmente. Estos derechos comprenden el derecho de esos pueblos a participar en la utilización, administración y conservación de dichos recursos". La inscripción de las tierras bajo dominio del Estado no lo exime de la aplicación del artículo 15 del Convenio (párrafo $2^{\circ}$ ). Es decir, el Convenio contiene disposiciones particulares para los territorios tradicionalmente ocupados por los pueblos indígenas que sean propiedad del Estado pero no los excluye del campo de aplicación del Convenio. Por el contrario, el párrafo $2^{\circ}$ del artículo 15 del Convenio está redactado justamente para los casos en que pertenezca al Estado la propiedad del subsuelo o de los recursos naturales ${ }^{99}$.

Lo estipulado en el artículo 15 debe leerse en concordancia con los artículos 6 y 7 del Convenio, lo cual se traduce en la obligación de los gobiernos de velar por que las comunidades indígenas interesadas sean consultadas oportuna y adecuadamente sobre el alcance y las implicaciones de las actividades de exploración y explotación, sea de actividades mineras, petroleras o forestales ${ }^{100}$. El gobierno debería tomar las medidas adecuadas para que los pueblos interesados participen siempre que sea posible en los beneficios que reporten tales actividades y para que perciban una indemnización equitativa por cualquier daño que puedan sufrir como resultado de esas actividades según lo establece el párrafo 2 de este artículo ${ }^{101}$.

El artículo 15 supone la obligación de consultar a los pueblos afectados cuando los recursos naturales se encuentren en las tierras in-

${ }^{98}$ Comisión de Expertos en Aplicación de Convenios y Recomendaciones, Solicitud directa individual sobre el Convenio sobre pueblos indígenas y tribales, Costa Rica, 1997, pár. 11 .

99 Comisión de Expertos en Aplicación de Convenios y Recomendaciones, Observación individual sobre el Convenio sobre pueblos indígenas y tribales, México, 2005, pár. 10 .

${ }^{100}$ Comité encargado de examinar la reclamación en la que se alega el incumplimiento por Bolivia del Convenio sobre pueblos indígenas y tribales, presentada en virtud del artículo 24 de la Constitución de la OIT por la Central Obrera Boliviana (COB), Informe, 1998, pár. 38.

101 Comisión de Expertos en Aplicación de Convenios y Recomendaciones, Solicitud directa individual sobre el Convenio sobre pueblos indígenas y tribales, Perú, 2003, pár. 3. 
dígenas definidas en el párrafo 2 del artículo 13 del Convenio. Esta norma establece que "la utilización del término tierras en los artículos 15 y 16 deberá incluir el concepto de territorios, lo que cubre la totalidad del hábitat de las regiones que los pueblos interesados ocupan o utilizan de alguna otra manera". Con ello, el Convenio no solamente atañe a las áreas ocupadas por los pueblos indígenas, sino que abarca también "el proceso de desarrollo, en la medida en que éste afecte a sus vidas... y a las tierras que ocupan o utilizan de alguna manera" (artículo 7.1). En consecuencia, la existencia de un proyecto de exploración o de explotación de proximidad inmediata a las tierras ocupadas o utilizadas de alguna manera por los pueblos indígenas, o que afecte directamente los intereses de dichos pueblos, caería dentro del alcance del Convenio ${ }^{102}$. Acorde con lo anterior, fue considerado impertinente el criterio utilizado por el gobierno de Colombia para determinar si la ubicación de un proyecto de exploración o explotación en una región particular afectaría a dichas comunidades. El enfoque empleado por este país decía relación con la "presencia regular y permanente de comunidades indígenas", lo cual resultaba excesivamente restrictivo a la luz de las normas convencionales ${ }^{103}$. Asimismo, se ha señalado que el Convenio no exige que los pueblos indígenas tengan títulos de propiedad a los fines de poder participar en la consulta prevista en el párrafo $2^{\circ}$ del artículo $15^{104}$.

La realización por parte de una empresa de estudios de impacto ambiental no reemplaza la consulta. La obligación de efectuar la consulta recae en el gobierno del país signatario y no en una empresa particular $^{105}$. En términos generales, en virtud del artículo 7.3 del Convenio se deberían efectuar estudios, en cooperación con los pueblos intere-

${ }^{102}$ Comisión de Expertos en Aplicación de Convenios y Recomendaciones, Observación individual sobre el Convenio sobre pueblos indígenas y tribales, Guatemala, 2007, pár. 5 .

${ }^{103}$ Comité establecido para examinar la reclamación en la que se alega el incumplimiento por Colombia del Convenio sobre pueblos indígenas y tribales, presentada en virtud del artículo 24 de la Constitución de la OIT por la Central Unitaria de Trabadores (CUT), Informe, 1999, pár. 86.

${ }^{104}$ Comité encargado de examinar la reclamación en la que se alega el incumplimiento por Guatemala del Convenio sobre pueblos indígenas y tribales, presentada en virtud del artículo 24 de la Constitución de la OIT por la Federación de Trabajadores del Campo y la Ciudad (FTCC), Informe, 2005, pár. 48.

105 Comisión de Expertos en Aplicación de Convenios y Recomendaciones, Observación individual sobre el Convenio sobre pueblos indígenas y tribales, Guatemala, 2006, pár. 13. 
sados, a fin de evaluar la incidencia social, espiritual y cultural y sobre el medio ambiente que las actividades de desarrollo previstas puedan tener sobre esos pueblos. Al respecto, el mismo artículo dispone que "los resultados de estos estudios deberán ser considerados como criterios fundamentales para la ejecución de las actividades mencionadas". En conclusión, los estudios de impacto ambiental previstos en la ley no son suficientes a efectos de este artículo, sino que deben incluir la incidencia "social, espiritual y cultural" y realizarse en cooperación con los pueblos interesados ${ }^{106}$.

La jurisprudencia aquí reseñada permite sostener que los órganos de la OIT emplean en su labor los criterios de interpretación acordes con lo establecido en el derecho internacional, y en particular con lo plasmado en el párrafo $1^{\circ}$ del artículo 31 de la Convención de Viena sobre el Derecho de los Tratados del año 1969107. Dichos cánones interpretativos tienen como consecuencia la confirmación de que, bajo el Convenio 169, las obligaciones de los Estados signatarios poseen un vasto alcance y requieren de una re-ingeniería fundamental de la administración pública y los procesos legislativos. A continuación se analiza cómo algunos de los países miembros del Convenio han emprendido la implementación de las obligaciones que consagra.

\section{ESTUDIOS DE CASO DE POLÍTICAS PÚBLICAS}

La sección anterior ilustró las formas de supervisión desarrolladas por la OIT con el fin de asegurar la implementación del Convenio 169. Si bien no se trata de un órgano jurisdiccional, su labor ofrece numerosas indicaciones respecto de la aplicación práctica de ese instrumento internacional. Paralelamente, surge la pregunta acerca de la procedencia de la aplicación directa del Convenio 169 por los tribunales locales. Un reciente estudio elaborado por la OIT demuestra que en algunos países signatarios, los tribunales nacionales son los órganos que

${ }^{106}$ Comité encargado de examinar la reclamación en la que se alega el incumplimiento por Brasil del Convenio sobre pueblos indígenas y tribales, presentada en virtud del artículo 24 de la Constitución de la OIT por el Sindicato de Ingenieros del Distrito Federal (SENGE/DF), Informe, 2006, pár. 57.

107 Dicho precepto señala: "Un tratado deberá interpretarse de buena fe conforme al sentido corriente que haya de atribuirse a los términos del tratado en el contexto de estos y teniendo en cuenta su objeto y fin". 
están a la vanguardia de la aplicación del Convenio ${ }^{108}$. Dentro del compendio señalado, destaca en particular la jurisprudencia de los tribunales de Colombia y especialmente de su Tribunal Constitucional. Dicha jurisprudencia se caracteriza por un alto nivel de elaboración dogmática y por el notorio impacto práctico con el que determinados derechos de los pueblos indígenas fueron afirmados por los tribunales de ese país ${ }^{109}$.

Sin perjuicio de lo anterior, acorde con las disposiciones del Convenio 169, su implementación recae sobre los gobiernos de los países firmantes, quienes deben garantizar la existencia de instituciones, recursos y medidas legislativas requeridos para ello (artículos 2 y 33 del Convenio). El Convenio 169 cuenta con un total de 20 ratificaciones, la mayoría de las cuales corresponde a países latinoamericanos, a los que se suman España, Holanda, Noruega y Dinamarca, Fidji y Nepal ${ }^{110}$. Como se verá a continuación, en algunos de los casos, las medidas prescritas por el Convenio 169 se incorporan en las políticas indígenas generales del país. La presente sección describe la implementación del Convenio 169 en los sistemas jurídicos nacionales de Noruega, México y Argentina, escogidos como ejemplos de realidades socioculturales distintas, pero con un importante despliegue de medidas conducentes a la implementación de las normas convencionales.

\subsection{Noruega}

Noruega es el país nórdico con mayor población saami (los otros son Suecia, Finlandia y Rusia) ${ }^{111}$, y es el único de ellos y primero de la totalidad de los países que han ratificado el Convenio 169.

Hasta los años setenta, los intereses saami no fueron objeto de consideración por las autoridades noruegas. Los saami eran vistos más bien como destinatarios de políticas de asimilación y de numerosas me-

108 Organización Internacional del Trabajo (OIT), "La aplicación del Convenio Núm. 169 por tribunales nacionales e internacionales en América Latina”, 2010, http:// www.ilo.org/indigenous/Resources/Publications/lang--en/docName--WCMS_123946/ index.htm.

${ }^{109}$ Ibíd., pp. 64-127.

${ }^{110}$ Organización Internacional del Trabajo (OIT), http://www.ilo.org/ilolex/spanish/newratframeS.htm.

111 John Henriksen, "The Continuos Process of Recognition and Implementation of the Samiu People's Right to Self-Determination”, 2008, pp. 27-28. 
didas orientadas a separarlos de su tradicional forma de vida ${ }^{112}$. Los saami tampoco fueron concebidos por las autoridades como pueblos indígenas, contrariamente a la opinión defendida al comienzo por los funcionarios del Ministerio Exterior. Entre los años 1979 y 1982 se produce un conflicto entre las autoridades y la sociedad civil con relación a la construcción de la represa sobre el río Alta-Kautokeino, en el cual intervienen los grupos ambientalistas y los saami ${ }^{113}$. Aunque en esta ocasión la Corte Suprema falló a favor del gobierno, el caso puso el tema frente a toda la nación y exigió replantear las políticas hacia la asimilación de los saami. Ello condujo a la constitución de la Comisión de los Derechos de los Saami, la que colaboró en la aprobación de la Ley sobre sus derechos en el año 1987 y en la reforma de la Constitución que en el año 1988 reconoció a los saami como un pueblo de Noruega ${ }^{114}$. Ese cambio de paradigma en la política de Noruega se hizo también notar en la forma en que participó en la negociación del Convenio 169. Al inicio, una de las principales inquietudes de ese Estado fue el tema del derecho sobre las tierras. El delegado en la Conferencia proponía equiparar la noción "derecho de propiedad" a la "derecho de uso" o "derecho de uso preferencial". La propuesta fue rechazada por la Conferencia por debilitar el nivel de protección en comparación con el Convenio 107. En la última fase de negociación, Noruega retiró su propuesta de modificación con ánimo de avanzar en la aprobación del Convenio $169^{115}$.

La Ley sobre el Parlamento Saami y Otras Materias Relacionadas con los Saami (Ley No 56 de 12 de junio de 1987) establece un Parlamento Saami, cuyos representantes son elegidos por la población saami de todo el país. Los gastos relacionados con las elecciones son cubiertos por el Estado. Tienen derecho a voto todas las personas que participen en elecciones municipales y que se encuentren inscritas en los registros de votantes saami. Dicho registro abarca a aquellas personas que se consideran saami, o bien que hablan idioma saami como su lengua materna en su hogar o tienen a un padre o abuelo que hable saami como

112 Malgosia Fitzmaurice, "The New Developments Regarding the Saami Peoples of the North", 2009, p. 84.

113 Henry Minde, "Sami Land Rights in Norway: A Test Case for Indigenous Peoples", 2001, p. 113.

114 Malgosia Fitzmaurice, "The New Developments Regarding the Saami Peoples of the North", 2009, p. 89.

115 Henry Minde, "Sami Land Rights in Norway: A Test Case for Indigenous Peoples”, 2001, pp. 118 y 120. 
su lengua materna en el hogar. Cualquier persona incluida en el registro puede, asimismo, postular a un escaño en el Parlamento. La nominación del candidato debe estar firmada por a lo menos 15 saami.

El Parlamento tiene poder de decisión cuando así lo establece la ley y su competencia se extiende a todas las materias que afecten a los saami. El Parlamento puede, por su propia iniciativa, plantear temas dentro del ámbito de su competencia y pronunciarse sobre ellos. Las autoridades públicas deben dar al Parlamento la oportunidad de expresar su opinión antes de tomar cualquier decisión sobre los temas que están dentro de su ámbito de competencia.

La Ley, asimismo, reconoce un área administrativa para el idioma saami, dentro de la cual ese idioma se usa en forma paralela al noruego, tanto en los actos de órganos estatales y municipales, ante los tribunales, como en los sistemas de salud y de educación.

El 1 de junio de 2005 fue aprobado el documento llamado "Procedimientos de Consultas entre Órganos Estatales y el Parlamento de Saami”, elaborado con participación de este último. El Procedimiento se aplica con respecto a los temas relevantes para la cultura saami, incluyendo los derechos sobre la tierra. Las materias de naturaleza general que afecten a la sociedad en su totalidad no son objeto de consultas obligatorias $^{116}$. Las consultas tienen que efectuarse de buena fe, con el objeto de alcanzar acuerdo sobre las medidas propuestas. Las autoridades tienen la obligación de informar al Parlamento Saami sobre el inicio de cualquier iniciativa que los pueda afectar, y el Parlamento responderá tan pronto como sea posible si requiere realizar consultas. El Parlamento puede, asimismo, plantear los temas para consultas por su propia iniciativa. En los casos en los cuales hay acuerdo entre el Parlamento y las autoridades sobre la necesidad de realizar las consultas, se buscará elaborar un plan de trabajo en el marco de tiempo que permita realizar consultas genuinas y efectivas. En 2006, el Ministerio de Trabajo e Inclusión Social elaboró una guía comentada sobre la aplicación del Procedimiento. En el período 2005-2007, el Parlamento Saami y el Ministerio de Medioambiente condujeron una serie de consultas relativas al uso de los recursos naturales en las tierras habitadas por los saami, alcanzando un acuerdo sobre los trabajos para la conservación de la naturaleza en esa región ${ }^{117}$.

${ }^{116}$ Gobierno de Noruega, Informe a la OIT, 2008, http://www.regjeringen.no/se/ dep/aid/Fadda-/Samepolitihkka/Riikkaidgaskasa-algoalbmotbargu/report-on-conventionno-169-concerning-i.html?id=548646.

117 Ibíd. 
El siguiente paso en el desarrollo de la norma constitucional fue la aprobación de la Ley sobre la Regulación y Administración de Tierras y Recursos Naturales en el Condado de Finnmark $\left(\mathrm{N}^{\mathrm{o}} 85\right)^{118}$. Esta Ley creó un régimen administrativo especial en el territorio de la región Finnmark, cubriendo el 95\% de la misma y abarcando 72.600 habitantes ${ }^{119}$. Previo a su aprobación, el Parlamento de Noruega solicitó al Ministerio de Justicia designar expertos independientes con el fin de evaluar el potencial de la Ley de cumplir con las normas internacionales sobre los derechos indígenas. El informe que se citará a continuación da mayormente una respuesta negativa a la pregunta por la concordancia entre las normas más relevantes de la Ley y el Convenio $169^{120}$.

El artículo 1 de la Ley define su propósito como el de "facilitar una administración de las tierras y recursos naturales en el condado de Finnmark de una manera balanceada y ecológicamente sustentable para el beneficio de los habitantes del condado y en particular como base para la cultura saami, el pastoreo de renos, el uso de las áreas no cultivadas, la actividad comercial y vida social" (art. 1). La Ley deberá aplicarse con los parámetros $^{121}$ que establece el Convenio $169 \mathrm{y}$ de conformidad con las normas del derecho internacional relativo a los derechos indígenas, con observación de los tratados internacionales de pesca. Sin embargo, la Ley no establece cómo resolver un conflicto entre una norma eventualmente incompatible con el Convenio $169^{122}$.

La Propiedad de Finnmark (Finnmarkseiendommen, Finnmárkkuopmodat o Finnmark Estate) es un ente legal independiente, que se constituye en propietario y administrador de las tierras y recursos naturales bajo su jurisdicción. Es administrado por un directorio compues-

${ }^{118}$ Ley sobre la Regulación y Administración de Tierras y Recursos Naturales en el Condado de Finnmark, de 17 de junio de 2007, www.regione.taa.it/biblioteca/minoranze/norvegia1.pdf.

119 Malgosia Fitzmaurice, "The New Developments Regarding the Saami Peoples of the North", 2009, p. 100.

${ }^{120}$ Hans Setter Graver y Geir Ulfstein, "The Sami People's Right to Land in Norway", 2004, pp. 337-377.

${ }^{121}$ La traducción al inglés usa la expresión "limitations", sin embargo la palabra noruega "begrensninger" también puede ser traducida como "parameters". Barbara Ann Hocking, "Land and Natural Resource Management in the Context of International Obligations to Indigenous Citizens: A Case Study of Norway's Finnmark Act", 2005, nota 10 .

122 Hans Setter Graver y Geir Ulfstein, “The Sami People's Right to Land in Norway", 2004, p. 361. 
to por seis personas elegidas por cuatro años renovables, sin que puedan permanecer en el cargo por más de diez años. El Parlamento Saami elige a tres de ellas y otras tres son designadas por la administración del condado. Un miembro sin derecho a voto es designado por el Rey. De las personas elegidas por el Parlamento, por lo menos una tiene que representar a los pastores de renos. El sistema establecido, sin embargo, no distingue entre los territorios de los saami y aquellos administrados por la Propiedad de Finnmark y no se otorgan derechos especiales a los saami como pueblo indígena ${ }^{123}$. Frente a ello se observa que la composición del directorio, el rol de los lineamientos que emite el Parlamento Saami y las reglas de la toma de decisiones sobre la disposición sobre las tierras, no les otorgan a los saami los derechos dominantes de administración de las tierras que exige el Convenio 169124. Si bien la Ley establece que la administración de un territorio más grande que el habitado tradicionalmente por los saami debe efectuarse de manera que tome en cuenta las necesidades de su desarrollo, no excusa - desde la perspectiva del Convenio 169 - la inobservancia de la obligación de reconocer sus derechos de propiedad sobre aquellas tierras ${ }^{125}$.

Determinante resulta lo establecido en el artículo 5 de la Ley: "A través del uso prolongado de tierras y aguas los saami han adquirido, colectiva e individualmente, derechos sobre la tierra en Finnmark". Interesa destacar que ya desde fines de los años sesenta la jurisprudencia noruega ha ido reconociendo - aunque no siempre de manera constante- los derechos consuetudinarios de los saami sobre determinados territorios para realizar las actividades de pastoreo de renos. Tal jurisprudencia se consolida en forma definitiva con dos sentencias dictadas por la Corte Suprema en el año 2001, en las cuales el concepto de derechos consuetudinarios fue desarrollado a la luz de las características propias de la actividad de pastoreo ${ }^{126}$.

El Parlamento Saami puede entregar lineamientos para evaluar los efectos que tendrían los cambios de uso de las tierras incultivadas en la vida cultural y socioeconómica de los saami. Tales lineamientos deberían ser aprobados por el poder ejecutivo, el que evaluará si han

${ }^{123}$ Ibíd., p. 356.

${ }^{124}$ Ibíd., pp. 357 y ss.

${ }^{125}$ Ibíd., p. 362.

126 Eva Josefsen, "Norwegian Legislation and Administration - Saami Land Rights", 2007, pp. 12-15. 
sido formulados dentro del marco establecido por la norma recién mencionada. Un desacuerdo sobre el contenido de los lineamientos entre el ejecutivo y el Parlamento conduce a su no aprobación. Los lineamientos del Parlamento tienen que seguirse a la hora de decidir acerca de los cambios propuestos. En otras palabras, el Parlamento Saami no posee la última palabra sobre el contenido de los lineamientos ${ }^{127}$.

Una evaluación de lo anterior señala que la Ley no cumple con el art. 14 del Convenio, en particular con la frase primera del inciso primero, dado que no les reconoce a los saami "derechos de propiedad y posesión sobre las tierras que tradicionalmente ocupan". Esta norma no exige entregar un título de propiedad a los pueblos indígenas. Pero su interpretación a la luz de otros preceptos del Convenio, en particular los artículos 13 y 7, hace ver que los niveles de protección que ofrece la frase primera del inciso primero no pueden ser equiparados a los consagrados en la frase segunda, o en otras palabras, no pueden sustituirse por el derecho a utilizar las tierras a las que tradicionalmente hayan tenido acceso para garantizar su subsistencia ${ }^{128}$. Lo que requiere el art. 14 en su primera frase es que en las áreas tradicionalmente habitadas por los saami, a ellos se les reconozcan los derechos que en el sentido legal y de facto correspondan a derechos de propiedad bajo la ley noruega ${ }^{129}$.

La Propiedad de Finnmark administra los recursos naturales renovables de conformidad con las leyes sobre la protección de la naturaleza y distintas especies. A través de los artículos 22 a 28, la ley establece derechos de caza, pesca, talado de árboles y la recolección de frutas en el territorio de Finnmark y la forma de regularlos por parte de la Propiedad de Finnmark. Tales derechos son más extensos para los habitantes del territorio que para aquellas personas no habitantes. Los derechos de estas últimas a efectuar esas actividades podrían ser restringidos o sometidos al pago de una licencia. Sin embargo, el régimen establecido no ha estado exento de crítica, principalmente porque el derecho a aprovechar los recursos renovables, que va más allá de las normas generales del derecho noruego, ha sido otorgado a los habitantes de Finnmark, sin favorecer exclusivamente a los saami. Asimismo, la crí-

${ }^{127}$ Hans Setter Graver y Geir Ulfstein, "The Sami People's Right to Land in Norway", 2004, p. 359.

${ }^{128}$ Ibíd., pp. 352-355.

${ }^{129}$ Ibíd., p. 357. 
tica ha apuntado a que los derechos de administración de tales recursos no les fueron transferidos, ni siquiera en las tierras que les pertenecieran debido a su uso desde tiempos inmemoriales ${ }^{130}$.

La experiencia de Noruega permite apreciar que un esquema administrativo que pone de relieve algunas de las facultades de autogobierno de los pueblos originarios no es automáticamente compatible con las exigencias plasmadas en el Convenio 169. La sofisticación del sistema desarrollado en el caso de Noruega queda corta frente a la interpretación de las normas convencionales en el sentido corriente de los términos que suelen emplear los órganos de la OIT.

\subsection{México}

A inicios del siglo XX el Estado mexicano había desplegado una política destinada a resolver "el problema indígena", buscando para ello lograr una integración o asimilación de los pueblos originarios a la sociedad nacional. En el año 1948 se creó el Instituto Nacional Indigenista (INI), dependiente del Ministerio de Educación, institución que definía su contribución a este emprendimiento de la siguiente manera: "Nuestro problema indígena no es el de conservar indígena al indígena ni el de indigenizar a México, sino el de mexicanizar al indígena."131.

Recién en la Constitución de 1992, trascurridos dos años desde la ratificación por parte de México del Convenio 169 de la OIT, el estatus legal específico de los pueblos indígenas fue por primera vez reconocido a nivel de la Constitución Política del Estado. Sin embargo, tal reconocimiento había sido restringido únicamente a lo relacionado con los derechos culturales de los pueblos originarios ${ }^{132}$, limitación que, a lo largo de los años noventa, impulsó diversas iniciativas de reforma constitucional. Entre ellas figuró el proyecto encargado en 1996 a la Comisión de Concordia y Pacificación (COCOPA), cuya elaboración no prosperó debido a la ruptura del diálogo entre el Ejecutivo mexicano y el Ejército Zapatista de Liberación Nacional. No obstante, dicho pro-

${ }^{130}$ Ibíd., pp. 366-371.

131 Presidente Cárdenas en el Primer Congreso Indigenista Interamericano realizado en Pátzcuaro en 1940, citado por Pierre Beaucage y Rosa Cusminsky, "La Condición Indígena en México", 1988, p. 207.

${ }^{132}$ Shannon Speed y Jane F. Collier, "Limiting Indigenous Autonomy in Chiapas, Mexico: The State Government's Use of Human Rights”, 2000, p. 883. 
yecto, aunque sufrió importantes modificaciones, sirvió de base para la reforma constitucional aprobada por el Congreso el 25 de abril de $2001^{133}$. Con ello, fueron reformados los artículos $1^{\circ}, 2^{\circ}, 4^{\circ}, 18$ y 115 de la Constitución. El artículo $2^{\circ}$ constituye el pilar fundamental de la nueva normativa, a través del cual se introduce un concepto más elaborado de los pueblos indígenas, se establece un catálogo avanzado de sus derechos y, como correlato de éstos, se consagra una serie de obligaciones de acción de los poderes públicos del Estado.

En cuanto a la definición de los pueblos indígenas, el nuevo artículo $2^{\circ}$ de la Constitución afirma que "la Nación Mexicana es única e indivisible", y junto con ello reconoce que "la Nación tiene una composición pluricultural sustentada originalmente en sus pueblos indígenas que son aquellos que descienden de poblaciones que habitaban en el territorio actual del país al iniciarse la colonización y que conservan sus propias instituciones sociales, económicas, culturales y políticas, o parte de ellas." Con ello, la diferencia cultural se consagra - en reemplazo del concepto de la nación homogénea y "mestiza"- como uno de los pilares fundamentales del Estado mexicano, y que se desglosa a través de disposiciones relativas a los principios del pluralismo cultural, político y jurídico ${ }^{134}$. El inciso siguiente de la norma recoge, en sintonía con lo establecido en el Convenio 169, el criterio subjetivo de autoadscripción al señalar que "la conciencia de su identidad indígena deberá ser criterio fundamental para determinar a quienes se aplican las disposiciones sobre pueblos indígenas". Al mismo tiempo se introduce el concepto de "comunidades integrantes de un pueblo indígena", que son aquellas que "formen una unidad social, económica y cultural, asentadas en un territorio y que reconocen autoridades propias de acuerdo con sus usos y costumbres". Corresponde a "las constituciones y leyes de las entidades federativas" el reconocimiento de los pueblos y comunidades indígenas.

Sin embargo, la reforma constitucional no llegó a otorgarles a los pueblos y comunidades indígenas el estatus de sujetos de derecho público. De haber contado con dicho estatus, semejante al de un municipio o un estado federal, habrían sido considerados como personas jurídicas

${ }^{133}$ María del Pilar Pérez Sánchez, Multiculturalismo: Derecho de Participación Politica de las Minorías Indígenas, 2009, pp. 74-75.

134 Jorge Alberto González Galván, Los Derechos del Pueblo Mexicano: México a Través de sus Constituciones, 2006, p. 403. 
creadas por ley, con plena capacidad jurídica para ejercer sus derechos y contraer obligaciones. En cambio, su estatus actual corresponde al de los "sujetos de interés público", que "encarnan el conjunto de pretensiones relacionadas con las necesidades colectivas de los miembros de una comunidad y protegidas mediante la intervención directa y permanente del Estado". ${ }^{135}$ Esta situación fue criticada por la OIT ${ }^{136}$ y, asimismo, a nivel del gobierno mexicano se ha reconocido que la regulación constitucional es insuficiente, dado que impide a los pueblos indígenas hacer valer sus derechos en calidad de sujetos: "En el caso de los pueblos y comunidades indígenas, su mención y definición en la Constitución Federal no bastan para probar su existencia legal, se requiere la manifestación expresa del legislador para conformar entidades de derecho público que gocen de personalidad y capacidad jurídica plenas, con todas las consecuencias legales inherentes: no sólo capacidad de goce (como en el caso de las entidades de interés público) sino, más acabadamente, capacidad de ejercicio (elemento inmanente al sujeto de derecho público). Mientras esto no suceda su existencia no puede ser probada legalmente y por lo tanto no pueden contraer obligaciones ni ejercer sus derechos como entidad colectiva"137.

Conforme a lo señalado en el artículo $2^{\circ}$ de la Constitución, el reconocimiento de los pueblos y comunidades indígenas se realiza a través de las "constituciones y leyes de las entidades federativas, las que deberán tomar en cuenta, además de los principios generales establecidos en los párrafos anteriores de este artículo, criterios etnolingüísticos y de asentamiento físico." Ante la pregunta por la forma en que las leyes federales deben abordar la regulación de este asunto, la Suprema Corte de Justicia de México resolvió que ninguna ley secundaria pueda limitar las disposiciones constitucionales correspondientes, pero que éstas son susceptibles de ser ampliadas por el legislador ordinario, ya sea federal o local. Los congresos locales, al legislar sobre lo dispuesto en el artículo $2^{\circ}$ de la Constitución, deben hacerlo bajo el criterio de que los derechos otorgados a la población indígena "son derechos mínimos que

135 María del Pilar Pérez Sánchez, Multiculturalismo: Derecho de Participación Política de las Minorías Indígenas, 2009, p. 75.

${ }^{136}$ Comisión de Expertos en Aplicación de Convenios y Recomendaciones, Solicitud directa individual sobre el Convenio sobre pueblos indígenas y tribales, México, 2006.

137 Comisión Nacional para el Desarrollo de los Pueblos Indígenas (CDI), La Vigencia de los Derechos Indígenas en México 2007, 2007, p. 32. 
deben ser respetados para garantizar su efectividad, pero que pueden ser ampliados para imprimir las características propias que mejor expresen las situaciones y aspiraciones de sus pueblos indígenas, siempre que tal ampliación se realice sin vulnerar el marco constitucional al que dichos derechos se encuentran sujetos"138.

Aunque las constituciones estatales regulan el reconocimiento y los derechos de los pueblos y comunidades indígenas de manera consistente con la Constitución Federal ${ }^{139}$, solamente algunos estados - Oaxaca, San Luis Potosí, Querétaro y Durango- reconocieron la personalidad jurídica de derecho público a los pueblos y comunidades indígenas ${ }^{140}$. Así por ejemplo, la Constitución del estado de Oaxaca establece en su artículo 16: "El Estado de Oaxaca tiene una composición étnica plural, sustentada en la presencia y diversidad de los pueblos y comunidades que lo integran. El derecho a la libre determinación de los pueblos y comunidades indígenas se expresa como autonomía, en tanto partes integrantes del Estado de Oaxaca, en el marco del orden jurídico vigente; por tanto dichos pueblos y comunidades tienen personalidad jurídica de derecho público y gozan de derechos sociales. La ley reglamentaria establecerá las medidas y procedimientos que permitan hacer valer y respetar los derechos sociales de los pueblos y comunidades indígenas" $" 141$.

En lo relativo al catálogo de los derechos de los pueblos indígenas, el artículo $2^{\circ}$ de la Constitución reconoce su derecho a la libre determinación, el que "se ejercerá en un marco constitucional de autonomía que asegure la unidad nacional". Seguidamente, la disposición se desglosa en dos apartados: el apartado A, que precisa los derechos políticos de los que gozan con el fin de hacer valer el derecho de libre determinación, y el apartado B, que contempla las obligaciones de la

${ }^{138}$ Citado por Erica Lily Díaz, Nahieli Gómez y Norma González et al., "Estrategias de Defensa para los Pueblos Indígenas", Litígio Estratégico en México: La Aplicación de los Derechos Humanos a Nivel Práctico. Experiencias de la Sociedad Civil, 2007, p. 76.

139 Jorge Ulises Carmona Tinoco, "La Incorporación de los Derechos Humanos en las Constituciones Locales Mexicanas", Memorias del Seminario la Armonización de los Tratados Internacionales de Derechos Humanos en México, 2005, p. 109.

${ }^{140}$ Comisión Nacional para el Desarrollo de los Pueblos Indígenas (CDI), La Vigencia de los Derechos Indígenas en México 2007, 2007, p. 32.

${ }^{141}$ Constitución del estado de Oaxaca, http://www.redindigena.net/leyes/mex/ esta/consti/oaxaca.html. 
Federación, de los estados y municipios, tendientes a facilitar el ejercicio de tales derechos.

Los derechos consagrados en el apartado A podrían ser agrupados en derechos relativos al (a) autogobierno, (b) preservación de la identidad cultural y de lenguas originarias, (c) aplicación de las normas tradicionales y acceso a justicia, y (d) acceso a las tierras y recursos naturales.

Respecto del primero de esos derechos, el artículo $2^{\circ}$ establece entre otras cosas que las comunidades indígenas podrán elegir, en los municipios con población indígena, representantes ante los ayuntamientos. El 15 de julio de 2004, el Consejo General del Instituto Federal Electoral (IFE) emitió el Acuerdo, aprobado en consultas con los pueblos indígenas, por medio del cual se establecieron los criterios para la división del territorio nacional en distritos electorales federales uninominales. A partir del 11 de febrero de 2005 el Consejo General del IFE aprobó la demarcación territorial de los 300 distritos electorales federales uninominales en los que se divide el país para los procesos electorales a efectuarse hasta el año 2009. Durante el proceso de demarcación de los distritos, se tomó en cuenta a la población indígena como un criterio para la conformación de los distritos electorales. Como resultado de este proceso, existen 28 distritos electorales indígenas, esto es, distritos en los cuales la población indígena representa el $40 \%$ o más de la población ${ }^{142}$.

Sin perjuicio de lo anterior, llama la atención el artículo $115^{\circ}$ de la Constitución, el que señala que "las comunidades indígenas, dentro del ámbito municipal, podrán coordinarse y asociarse en los términos y para los efectos que prevenga la ley". La norma modificó la propuesta inicial del proyecto de COCOPA, que contemplaba el derecho al "ejercicio de la libre determinación de los pueblos indígenas en cada uno de los ámbitos y niveles en que hagan valer su autonomía, pudiendo abarcar uno o más pueblos indígenas". El tenor de la disposición vigente ha sido objeto de crítica, dado que restringe los derechos de los pueblos indígenas en tanto sólo podrían ser ejecutados a través de las comunidades dentro del ámbito municipal y de conformidad a la legislación vigente ${ }^{143}$.

142 Comisión Nacional para el Desarrollo de los Pueblos Indígenas (CDI), La Vigencia de los Derechos Indígenas en México 2007, 2007, pp. 24-25.

143 Marco Aparicio Wilhelmi, "La Libre Determinación y la Autonomía de los Pueblos Indígenas. El Caso de México”, 2009, pp. 26-27. 
Para promover los derechos relacionados con el uso de las lenguas indígenas, en 2003 fue aprobada la Ley General de los Derechos Lingüísticos de los Pueblos Indígenas ${ }^{144}$. En su artículo $7^{\circ}$, la Ley establece que "las lenguas indígenas serán válidas, al igual que el español, para cualquier asunto o trámite de carácter público, así como para acceder plenamente a la gestión, servicios e información pública". Para garantizar el cumplimiento de esos derechos, los gobiernos territoriales, "en consulta con las comunidades indígenas originarias y migrantes, determinarán cuáles de sus dependencias administrativas adoptarán e instrumentarán las medidas para que las instancias requeridas puedan atender y resolver los asuntos que se les planteen en lenguas indígenas". En cambio, en los municipios con comunidades en las que se hablen lenguas indígenas se deben adoptar tales medidas en todas sus instancias. Junto con lo anterior se establece la prohibición de discriminación basada en las distinciones idiomáticas ${ }^{145}$, y se consagran numerosos derechos relativos al aprendizaje y goce de las lenguas nativas en el Instituto Nacional de Lenguas Indígenas (INALI) ${ }^{146}$, creado bajo el alero de la Secretaría de Educación Pública, cuyo objeto es "promover el fortalecimiento, preservación y desarrollo de las lenguas indígenas que se hablan en el territorio nacional, el conocimiento y disfrute de la riqueza cultural de la Nación, y asesorar a los tres órdenes de gobierno para articular las políticas públicas necesarias en la materia”. El INALI ha desplegado numerosas actividades relacionadas con la producción de catastros y normalización de las lenguas indígenas, y con la elaboración y enseñanza de reglas de traducción ${ }^{147}$.

En materias jurídicas, el artículo $2^{\circ}$ de la Constitución garantiza a los pueblos indígenas el derecho de "aplicar sus propios sistemas normativos en la regulación y solución de sus conflictos internos, sujetándose a los principios generales de esta Constitución, respetando las garantías individuales, los derechos humanos y, de manera relevante, la dignidad e integridad de las mujeres". La tensión entre las normas tradi-

${ }^{144}$ Diario Oficial de la Federación, 21 de mayo de 2003.

${ }^{145}$ Los estudios muestran que hasta el español hablado con algún acento indígena constituye causa de discirminación en los ámbitos social y laboral. Véase Roland Terborg, Laura García Landa y Pauline Moore, "The Language Situation in Mexico", 2006, pp. 488-500.

${ }^{146}$ Para mayor información véase http://www.inali.gob.mx.

${ }^{147}$ Dirección General de Derechos Humanos y Democracia, Secretaría de Relaciones Exteriores de México, "Derechos Humanos: Agenda Internacional de México", 19 de mayo de 2009. 
cionales y los principios generales de garantías individuales no deja de ser importante, como ilustra el caso de una localidad en la cual algunas personas indígenas fueron detenidas en forma preventiva y sometidas a un juicio tradicional, lo cual podría considerarse atentatorio al principio del debido proceso. Los afectados, si bien no reconocieron las responsabilidades que les habían sido imputadas, asumieron determinados compromisos de conducta para el futuro, lográndose finalmente la tranquilidad dentro de la comunidad ${ }^{148}$.

A partir de la enmienda constitucional, se han efectuado asimismo modificaciones en códigos penales adjetivos y sustantivos. En particular, fueron introducidas normas específicas para facilitar tanto el uso de los idiomas nativos en los juicios como la disponibilidad de intérpretes en los procedimientos, como asimismo para garantizar la consideración de las costumbres locales y regular las condiciones de encarcelamiento de personas indígenas ${ }^{149}$. Es interesante destacar que en el año 2006 se llegó a interponer un recurso de amparo ante la Corte Suprema de México en el idioma chinanteco. El recurso buscaba revocar un auto de prisión dictado contra un ciudadano indígena que había sido sorprendido portando marihuana. Debido a su liberación, el procedimiento de amparo fue sobreseído ${ }^{150}$.

En cuanto al derecho de los pueblos indígenas sobre las tierras, éste se define a través del numeral $\mathrm{VI}^{\circ}$ como el de "acceder, con respeto a las formas y modalidades de propiedad y tenencia de la tierra establecidas en esta Constitución y a las leyes de la materia, así como a los derechos adquiridos por terceros o por integrantes de la comunidad, al uso y disfrute preferente de los recursos naturales de los lugares que habitan y ocupan las comunidades, salvo aquellos que corresponden a las áreas estratégicas, en términos de esta Constitución. Para estos efectos las comunidades podrán asociarse en términos de ley". Este precepto debe ser leído en conjunto con el artículo $27^{\circ}$ de la misma Constitución

148 Shannon Speed y Jane F. Collier, "Limiting Indigenous Autonomy in Chiapas, Mexico: The State Government's Use of Human Rights", 2000, pp. 891 y ss.

149 Véanse, por ejemplo, los artículos 28 a 30, 87, 95, 103, 124, 124bis, 128, 146, 154, 220, 220bis, 223, 246, y 388 del Codigo Federal De Procedimientos Penales de México.

${ }^{150}$ Jorge Alberto González Galván, "El Primer Juicio de Amparo en Lengua Indígena: Los Idiomas del Derecho en el México Pluricultural del Siglo XXI", La Ciencia del Derecho Procesal Constitucional. Estudios en Homenaje a Héctor Fix-Zamudio en sus Cincuenta Años como Investigador del Derecho, 2008, p. 527. 
que consagra la estructura del régimen jurídico de propiedad en México y establece la propiedad originaria de la nación de las tierras y aguas comprendidas dentro de los límites del territorio nacional. La propiedad se divide en pública (patrimonio nacional o del Estado), privada (la de los particulares) y social (regímenes de tenencia de tierra ejidal y comunal). El segundo párrafo del numeral $\mathrm{VII}^{\circ}$ señala que la ley protegerá la integridad de las tierras de los grupos indígenas, pero este precepto no ha tenido desarrollo legislativo ${ }^{151}$. Lo anterior, unido a la falta de la personalidad jurídica de los pueblos indígenas bajo la ley mexicana, hacen compleja la implementación del derecho a modo de un derecho colectivo.

El apartado B del precepto consagra numerosas obligaciones de los poderes estatales, tendientes a "promover la igualdad de oportunidades de los indígenas y eliminar cualquier práctica discriminatoria". Las obligaciones más específicas abarcan las siguientes líneas de acción: impulsar el desarrollo económico de los pueblos indígenas; fortalecer la escolaridad y la educación bilingüe e intercultural, lo que incluye la obligación de establecer un sistema de becas; asegurar el acceso al sistema de salud, haciendo uso de la medicina tradicional y apoyando programas de nutrición, especialmente infantil; garantizar acceso a la vivienda, a los servicios sociales básicos y espacios de recreación; mejoramiento de la situación de las mujeres indígenas; extender las redes de comunicación, también con el fin de que puedan difundir su cultura; establecer facilidades económicas a la productividad y al desarrollo sustentable; proteger los derechos de los trabajadores migrantes y sus familias en el país y en el extranjero; incorporar los pueblos indígenas en la planificación del desarrollo nacional y estatal a través de las consultas; y garantizar partidas presupuestales destinadas para cumplir con estas obligaciones.

Como principal órgano promotor de esas políticas públicas se constituye la Comisión Nacional para el Desarrollo de los Pueblos Indígenas (CDI), sucesora del Instituto Nacional Indigenista. CDI opera en base a una ley del mismo nombre ${ }^{152}$ y cuenta con un Estatuto Orgánico ${ }^{153}$. Su misión general está definida por ley: “orientar, coordinar,

${ }^{151}$ Comisión Nacional para el Desarrollo de los Pueblos Indígenas (CDI), La Vigencia de los Derechos Indígenas en México 2007, 2007, p. 21.

${ }^{152}$ Diario Oficial de la Federación, el 21 de mayo de 2003.

${ }^{153}$ Diario Oficial de la Federación, el 13 de noviembre de 2006. 
promover, apoyar, fomentar, dar seguimiento y evaluar los programas, proyectos, estrategias y acciones públicas para el desarrollo integral y sustentable de los pueblos y comunidades indígenas de conformidad con el artículo $2^{\circ}$ de la Constitución Política" (art. 2 de la Ley). De ello se desprende que la CDI no define en forma autónoma políticas legislativas y administrativas en relación con los pueblos indígenas, en cambio funciona como órgano auxiliar en la etapa de su formulación y posee ciertas facultades en la etapa de implementación de estas políticas.

Esta funcionalidad auxiliar es, asimismo, reflejada en la estructura orgánica de la CDI, la cual es supervisada por una Junta de Gobierno, compuesta por los titulares de distintos ministerios y secretarías federales. La administración de la CDI recae en el Director General, designado y removido por el Presidente de la República. La participación de los pueblos indígenas en la CDI se plantea por intermedio del Consejo Consultivo, siendo éste un "órgano de consulta y vinculación con los pueblos indígenas y la sociedad" (art. 5 de la Ley). El Consejo es integrado por los representantes de los pueblos indígenas, de instituciones académicas y de investigación nacionales, especialistas en materia indígena, de organizaciones sociales que trabajen con las comunidades indígenas, por los integrantes de las mesas directivas de las Comisiones de Asuntos Indígenas de ambas Cámaras del Congreso de la Unión y por un representante de cada uno de los gobiernos de las entidades federativas en las que estén asentados pueblos y comunidades indígenas. Sin embargo, los representantes indígenas deben permanecer siempre en mayoría y uno de ellos presidirá las reuniones trimestrales del Consejo Consultivo.

Un análisis más pormenorizado de las acciones tomadas por las distintas entidades públicas superaría por completo los límites del presente estudio ${ }^{154}$. A modo de ejemplo, podemos señalar que, acorde al informe de la CDI correspondiente a las actividades del año 2008, destacan como logros más importantes el reconocimiento que se dio a la diversidad lingüística con la emisión por parte del Instituto Nacional de Lenguas Indígenas del Programa de Revitalización, Fortalecimiento y Desarrollo de las Lenguas Indígenas Nacionales 2008-2012; el inicio de

154 Véanse los informes anuales de la Comisión Nacional para el Desarrollo de los Pueblos Indígenas (CDI) en http://www.cdi.gob.mx, que dan cuenta de la labor legislaiva, administrativa, de programas y acciones y del desarrollo jurisprudencial en la materia, todo ello a nivel federal, estatal y municipal. 
la Consulta sobre los Mecanismos para la Protección de los Derechos de los Conocimientos Tradicionales, Expresiones Culturales, Recursos Naturales, Biológicos y Genéticos de los Pueblos Indígenas; la construcción de índices para analizar diferentes ámbitos de la realidad indígena de México; la difusión de la Declaración de las Naciones Unidas sobre los Derechos de los Pueblos Indígenas, mediante campañas radiales y la publicación de su texto en una edición de bolsillo con traducción a 20 lenguas indígenas. En total se habían realizado 58 programas o acciones federales, invirtiéndose $47.133,7$ millones de pesos mexicanos ${ }^{155}$. En cuanto a desafíos pendientes desde el punto de vista del Convenio 169, destaca la aprobación de la personalidad jurídica de los sujetos colectivos, la definición de las competencias de las autoridades indígenas, la participación política y la protección a los conocimientos tradicionales. También se subraya que si bien varios municipios con porcentaje elevado de población indígena cuentan con representantes ante el ayuntamiento, ello no ocurre todavía en municipios grandes como Monterrey y Guadalajara, ni en las delegaciones del Distrito Federal ${ }^{156}$.

Lo anterior permite apreciar que en México la implementación del Convenio 169 se ha visto fortalecida a través de una reforma constitucional que ha permitido elevar algunos de sus estándares a nivel de derechos y obligaciones de rango jurídico superior. Al mismo tiempo, a diferencia de Noruega donde el énfasis ha estado puesto en fortalecer el autogobierno de los pueblos indígenas, la implementación mexicana del Convenio 169 se realiza primordialmente a través de un despliegue de diversos programas gubernamentales tendientes a paliar determinadas situaciones de exclusión de los miembros de los pueblos indígenas.

\subsection{Argentina}

Durante el siglo XIX, bajo el discurso de un país "mestizo" o "blanco"157, los pueblos originarios de Argentina fueron sometidos a procesos de asimilación forzosa o sufrieron de campañas militares de

155 Comisión Nacional para el Desarrollo de los Pueblos Indígenas (CDI), Acciones de Gobierno para el Desarrollo Integral de los Pueblos Indígenas Informe 2008, 2009, pp. 401-402.

${ }^{156}$ Ibíd., p. 404.

157 Oscar Chamosa, "Indigenous or Criollo: The Myth of White Argentina in Tucumán’s Calchaquí Valley”, 2008, pp. 71-106. 
aniquilación $^{158}$. En el texto constitucional del año 1853 la referencia a los pueblos indígenas se hacía atribuyendo al Congreso de la Nación la facultad de "conservar el trato pacífico con los indios, y promover la conversión de ellos al catolicismo" (inciso 15 del art. 67). A lo largo del siglo XX, la importancia y visibilidad de los pueblos originarios en las políticas públicas del Estado argentino era fluctuante, aunque disminuyó particularmente durante los períodos de gobiernos dictatoriales. A partir de los años sesenta, de conformidad con las tendencias internacionales, comienzan a formularse políticas indígenas. En esos años Argentina ratifica el Convenio 107 de la OIT $^{159}$ y adhiere al Convenio 169 en el año 1992.

Previamente, en el año 1985, fue aprobada la Ley sobre política indígena y apoyo a las comunidades aborígenes, la que estipuló una serie de líneas de acción prioritarias en la materia. Tales políticas corresponden principalmente a tres ámbitos: el acceso de los pueblos indígenas a la propiedad de la tierra y el uso de ésta con fines de explotación económica (arts. 7-13); los derechos y programas en materia de educación (arts. 14-17), y la protección de la salud de sus integrantes (arts. 18-21). La implementación de la Ley estaba encomendada al Instituto Nacional de Asuntos Indígenas (INAI), establecido "como entidad descentralizada con participación indígena, que dependerá en forma directa del Ministerio de Salud y Acción Social" (art. 5). Sin embargo, el funcionamiento del INAI inicialmente había sido entorpecido por falta de un reglamento coherente que sentara las bases de su operatividad. El primer Reglamento fue aprobado recién en el año 1989, a través del Decreto 159, y fue seguido por el Decreto 667 del año 1991, el que oscureció aún más el estatus legal del Instituto. Frente a ello, las organizaciones indígenas iniciaron una acción ante la Justicia en lo Contencioso Administrativo Federal. El juicio terminó en el año 2000 y el dictamen del tribunal ordenó la institucionalización del INAI en los términos previstos por la Ley. La controversia fue definitivamente cerrada en el año 2003, cuando a través del decreto 246, destinado a dar cabal cumplimiento de la sentencia, el presidente del INAI fue finalmente designando ${ }^{160}$.

${ }^{158}$ Héctor Hugo Trinchero, "The Genocide of Indigenous Peoples in the Formation of the Argentine Nation-State”, 2006, pp. 127-133.

159 Claudia Lozano, "Indigenous People, Rights, and the State in Argentina", 2005, pp. 612-616.

${ }^{160}$ Lucia Martin, "El INAI-Instituto Nacional de Asuntos Indígenas", http:// www.indigenas.bioetica.org/inves47.htm. 
El INAI es dirigido por un presidente nombrado por el Ejecutivo y cuenta con un Consejo de Coordinación integrado por representantes de distintos ministerios y por "representantes elegidos por las comunidades aborígenes" (art. 5). Con el propósito de optimizar la participación de los pueblos indígenas en el INAI, el Instituto creó, en el año 2004, un Consejo de Participación Indígena (CPI) ${ }^{161}$, al que le corresponde determinar los criterios para escoger a los representantes en el Consejo de Coordinación junto con hacerse parte de la labor propia del mismo (art. 7). Los integrantes indígenas del CPI son elegidos por las comunidades que oportunamente deben haber obtenido la inscripción de su personería jurídica, ya sea en el Registro Provincial correspondiente o en el Registro Nacional de Comunidades Indígenas del INAI. Las autoridades de las comunidades inscritas pueden, por decisión de la asamblea, aceptar la participación de las autoridades de las comunidades que aún no se encuentren registradas (art. 1) ${ }^{162}$.

La función probablemente más importante del INAI consiste en llevar un registro de las comunidades indígenas. El artículo $2^{\circ}$ de la Ley reconoce la "personería jurídica a las comunidades indígenas radicadas en el país. Se entenderá como comunidades indígenas a los conjuntos de familias que se reconozcan como tales por el hecho de descender de poblaciones que habitaban el territorio nacional en la época de la conquista o colonización e indígenas o indios a los miembros de dicha comunidad". Sin embargo, "la personería jurídica se adquirirá mediante la inscripción en el Registro de Comunidades Indígenas", teniendo el INAI las facultades para evaluar la concurrencia de los elementos necesarios y otorgar o rechazar la inscripción (art. 3).

La reforma de la Constitución Política del año 1994 modificó el reconocimiento de los pueblos indígenas, pero lo hizo a través de la definición de las atribuciones del Congreso. En particular, en el órgano legislativo recaen las siguientes facultades: "Reconocer la preexistencia étnica y cultural de los pueblos indígenas argentinos. Garantizar el respeto a su identidad y el derecho a una educación bilingüe e intercultural; reconocer la personería jurídica de sus comunidades, y la posesión y propiedad comunitaria de las tierras que tradicionalmente ocupan; y regular la entrega de otras aptas y suficientes para el desarrollo humano; ninguna de ellas será enajenable, transmisible ni susceptible de gravá-

${ }^{161}$ Resolución INAI N 50168/2004 sobre la Creación del CPI.

162 Resolución INAI No 50168/2004 sobre la Modificación del CPI. 
menes o embargos. Asegurar su participación en la gestión referida a sus recursos naturales y a los demás intereses que los afecten. Las provincias pueden ejercer concurrentemente estas atribuciones" (inciso 17 del artículo 75 de la Constitución).

Llama la atención que los derechos de los pueblos indígenas no fueran consagrados de manera directa en la parte dogmática de la nueva Constitución. Ello se explica con los alcances restringidos de la ley declaratoria de la necesidad de la reforma constitucional. No obstante, existe la tendencia a considerar que la disposición tenía por finalidad proclamar derechos operativos en esta materia más allá de su ubicación metodológica dentro del texto constitucional ${ }^{163}$. De acuerdo con lo anterior, a través de la Resolución N 4811/96 del Secretario de Desarrollo Social, la mantención del Registro Nacional de Comunidades Indígenas fue adecuada a las disposiciones constitucionales, estableciendo "como únicos requisitos para la inscripción" la entrega del "nombre y ubicación geográfica de la comunidad, reseña que acredite su origen étnicocultural e histórico, con presentación de la documentación disponible; descripción de sus pautas de organización y de los mecanismos de designación y remoción de sus autoridades; nómina de los integrantes con grado de parentesco, mecanismos de integración y exclusión de sus miembros" (art. 1).

Sin perjuicio de lo anterior, en el año 2007 algunas provincias argentinas todavía tramitaban la personería jurídica de las comunidades indígenas bajo la forma de asociación civil. Lo anterior fue objeto de crítica por parte de la OIT, dado "que la asociación civil parece suponer la constitución de algo nuevo y no responde exactamente al principio del Convenio de reconocimiento de una realidad preexistente"164. Aunque la Corte Suprema de Justicia de la Nación, en el año 1997, siguiendo una serie de decisiones semejantes anteriores, falló que una "tribu" era una "entidad carente de personalidad jurídica"165. La idea defendida por la OIT fue acogida en el marco de una acción de amparo por la

163 Instituto Nacional de Asuntos Indígenas (INAI), http://www.desarrollosocial. gov.ar/INAI/site/institucional/derechos.asp.

164 Comisión de Expertos en Aplicación de Convenios y Recomendaciones, Solicitud directa individual sobre el Convenio sobre pueblos indígenas y tribales, Argentina, 2007.

165 Víctor Bazán, "Los Derechos de los Pueblos Indígenas en Argentina: Diversos Aspectos de la Problemática. Sus Proyecciones en los Ámbitos Interno e Internacional", 2003, p. 773-776. 
justicia argentina, en la cual se sostuvo "la personalidad jurídica de las Agrupaciones Indígenas es un hecho preexistente de la realidad y que impone al Estado su liso y llano reconocimiento sin otorgarle otro tipo de facultad en tal sentido, por ello se declara lo que ya existe, es decir la preexistencia de la personalidad jurídica de las comunidades y organizaciones indígenas". Teniendo en consideración que la posesión de la personalidad jurídica constituye un requisito indispensable para hacer valer los derechos, se ordenó a la provincia del Chaco que adopte "los recaudos legales necesarios a los fines de la Habilitación de un Registro de Comunidades y Organizaciones Indígenas con efecto Declarativo", y que en el plazo de cinco días proceda a inscribir la comunidad solicitante en dicho Registro ${ }^{166}$.

Otro tema tradicionalmente sensible en la implementación del Convenio 169 es el de propiedad sobre las tierras indígenas, y que en el caso argentino ha tenido dos matices importantes. La jurisprudencia de ese país ha reconocido ese derecho como un concepto distinto a aquel establecido en el código civil como un derecho de propiedad sostenido en un título. Así se ha fallado que "la posesión comunitaria de los pueblos indígenas no es la posesión individual del código civil. Por mandato operativo, categórico e inequívoco de la Constitución Nacional, toda ocupación tradicional de una comunidad indígena debe juzgarse como posesión comunitaria aunque los integrantes no hayan ejercido por sí los actos posesorios típicos de la ley inferior (artículo 2384 del código civil). Es la propia Constitución la que nos dice que esas comunidades han poseído y poseen jurídicamente por la sencilla razón de preexistir al Estado y conservar la ocupación tradicional. La posesión comunitaria y la propiedad comunitaria de los indígenas son categorías jurídicas nuevas que requieren, por supuesto, alguna adecuación normativa (...). Pero el derecho reconocido por el constituyente es plenamente operativo (...). Debe respetarse no bien se detecta una comunidad que persiste en su ocupación tradicional, aunque la adecuación normativa no esté completa" 167 .

166 Consejo Quompi -Lqataxac Nam Qompi- C/Provincia del Chaco Y/O Q.R.R. S/Acción de Amparo, No 8696/04, Juzgado Civil y Comercial, 21 de abril de 2006, http:// www.ceppas.org/gajat.

${ }^{167}$ Alfredo Sede y otros c/ Herminia Vila y otro s/ Desalojo, III ${ }^{\text {a Circunscripción }}$ Judicial de Río Negro. Juzgado de Primera Instancia en lo Civil, Comercial y Minería Nro. 5. Secretaría única San Carlos de Bariloche, 12 de agosto de 2004, http://www.indigenas.bioetica.org/fallo10.htm. 
No obstante esta visión de los tribunales, la creación del registro de comunidades indígenas encomendada a las provincias del país estaba significativamente atrasada. Ante la imposibilidad de la inscripción, las comunidades originarias carecían del estatus jurídico exigido por la ley, realidad que se transformaba en lesiones sistemáticas de sus derechos. En el año 2006, para paliar esta situación, fue promulgada la Ley $N^{\circ} 26.160$, llamada De Emergencia sobre Posesión y Propiedad de las Tierras que Ocupan las Comunidades Indígenas. La Ley suspendió durante el plazo de cuatro años "la ejecución de sentencias, actos procesales o administrativos, cuyo objeto sea el desalojo o desocupación de las tierras" de comunidades registradas, pero también de aquellas preexistentes (arts. 1 y 2), haya o no registrado su personería jurídica en el Registro Nacional de Comunidades Indígenas u organismo provincial competente (art. 1 del Reglamento de la Ley No. 26.160, aprobado por el Decreto 1.122/2007). Durante los tres primeros años, contados a partir de la vigencia de esta ley, el INAI tenía la obligación de realizar el relevamiento técnico-jurídico-catastral de la situación de dominio de las tierras ocupadas por las comunidades indígenas y promover las acciones que fueren pertinentes con el CPI, los institutos aborígenes provinciales, universidades nacionales, entidades nacionales, provinciales y municipales, organizaciones indígenas y organizaciones no gubernamentales (art. 3). Para lo anterior contaba con un Fondo Especial para la asistencia de comunidades indígenas por un monto de 30.000 .000 de pesos argentinos (art. 4). El 18 de noviembre de 2009, la vigencia de la Ley $\mathrm{N}^{\circ} 26.160$ fue prorrogada por tres años más (Ley $\left.\mathrm{N}^{\circ} 26.554\right)^{168}$.

Dentro de la misma línea de acción, a través del Decreto del Ejecutivo $\mathrm{N}^{\mathrm{0}} 700$ del 21 de mayo de 2010, se creó la Comisión de Análisis e Instrumentación de la Propiedad Comunitaria Indígena, que tendrá los siguientes objetivos: a) elevar al poder ejecutivo "una propuesta normativa para instrumentar un procedimiento que efectivice la garantía constitucional del reconocimiento de la posesión y propiedad comunitaria indígena, precisando su naturaleza jurídica y características; b) evaluar la implementación del Relevamiento Territorial de Comunidades Indígenas en el marco de las Leyes $\mathrm{N}^{\mathrm{o}} 26.160$ y No 26.554 , y c) elaborar iniciativas tendientes a unificar u homogeneizar el régimen legal

${ }^{168}$ Ley No 26.160 , http://www.ceppas.org/gajat/index.php?option=com_content $\&$ task= 
y de criterios de inscripción de las Comunidades Indígenas en todas las jurisdicciones"169.

En términos generales, la situación descrita presenta una cierta dualidad en cuanto al poder legislativo federal, y los tribunales ordinarios muestran mayor disposición frente a los elevados estándares del Convenio 169, por ejemplo, en lo que se refiere al reconocimiento de la personalidad jurídica preexistente de los pueblos originarios y sus derechos de propiedad sobre las tierras ancestrales. La implementación de las políticas públicas correspondientes, sin embargo, se ha visto retrasada, y requiere de una intervención consolidada de los poderes federales del Estado con el fin de profundizar los compromisos internacionales asumidos en materia de los derechos de los pueblos indígenas.

\section{CONCLUSIONES}

Este artículo ha indagado en los orígenes, la interpretación e implementación del Convenio 169 sobre derechos de los pueblos indígenas y tribales en países independientes. Los resultados del estudio pueden ser resumidos en las siguientes conclusiones:

1) La dedicación de la Organización Internacional del Trabajo a la regulación del tema indígena surge en el contexto de repartición de los territorios dominados por las potencias europeas que tiene lugar al finalizar la Primera Guerra Mundial. La OIT asumió un rol proactivo en la supervisión de los estándares mínimos de trato hacia los pueblos originarios de las colonias, siendo esa iniciativa intrínsicamente relacionada con el combate del trabajo forzoso. Entre los años 30 y 50, la OIT desarrolló numerosos estudios e implementó diversas acciones destinadas a fomentar el desarrollo en los países latinoamericanos, con lo cual consolidó su liderazgo en la regulación internacional de los derechos indígenas. La Organización formuló así la intención de consagrar estándares específicos de trato hacia los pueblos originarios que debieran promover su integración en las respectivas sociedades nacionales y mejorar su situación económica. Una gran parte del posicionamiento de la Organización en esta materia se debió al impulso inicial de su Secreta-

${ }^{169}$ Decreto del Ejecutivo No 700 del 21 de mayo de 2010, http://www.revistarap. com.ar. 
ría más que a la preocupación intrínseca de sus miembros. Sin embargo, esas iniciativas eran sistemáticamente acogidas por los poderes constituyentes de la OIT. De esta manera, en el año 1957, la OIT aprobó el Convenio 107 sobre poblaciones indígenas y tribales.

2) El Convenio 107 no logró producir un impacto práctico relevante. Las nociones antropológicas y desarrollistas que lo inspiraron habían quedado obsoletas a inicios de los años ochenta. Asimismo, en ese período, la ONU comenzó a abrirse a la posibilidad de regular los derechos de los pueblos indígenas. Con ello, el tradicional liderazgo de la OIT en la materia se ha visto disminuido. A iniciativa de la Secretaría de la OIT se inició la revisión del Convenio 107. El proyecto logró contar con el beneplácito de la ONU, presumiéndose que una nueva versión del Convenio debería circunscribirse a la promoción de "estándares técnicos" de políticas gubernamentales. Sin embargo, el nuevo texto fue concebido en términos más extensos que el anterior. En particular, se introdujo la noción de "pueblos indígenas" y se creó un importante catálogo de derechos de éstos, formulado en términos absolutos no subordinados a la realidad normativa de cada Estado. Aquel resultado parece cuestionable a la luz de la limitada competencia sustantiva de la Organización. Sin perjuicio de la compleja polémica en el seno de la OIT, el nuevo texto - el Convenio 169 sobre los Pueblos Indígenas y Tribales en los Países Independientes - encontró un abrumador apoyo en la Conferencia General de la OIT.

3) A partir de la Carta de la ONU que reconoció el derecho de todos los pueblos a la autodeterminación, se agudizó el desmantelamiento del sistema colonialista. Sin embargo, tal derecho correspondía únicamente a los pueblos dominados que se encontraban separados territorialmente de sus metrópolis. Con ello, las poblaciones indígenas en los Estados que ya habían alcanzado su independencia no estaban incluidas dentro de dichos procesos y quedaban marginadas de la posibilidad de transformarse en sujetos del derecho internacional. La defensa de sus intereses se efectúa por las vías de protección de las minorías raciales y étnicas. Un avance en la materia se produce en el año 2007, cuando la Asamblea General de la ONU aprobó la Declaración sobre los derechos de los pueblos indígenas. El carácter transversal de esta Organización hace de ella la instancia más adecuada para reflejar el consenso internacional en materia de derechos de los pueblos indígenas. Sin embargo, una Declaración de la Asamblea no constituye una normativa vincu- 
lante. Más aún, debido al vasto alcance de algunos de sus preceptos, la posibilidad de su pronta transformación en un instrumento internacional obligatorio tiene pronósticos reservados. Frente a este escenario, el Convenio 169 se mantiene como único instrumento internacional de naturaleza vinculante para los Estados que son sus signatarios.

4) El Convenio 169 emplea un concepto amplio de los "pueblos indígenas y tribales", que combina elementos objetivos socioculturales con aquellos subjetivos de autoidentificación. Conforme con dicha definición, el número de países que cuentan con poblaciones de esas características es elevado. No obstante, tan sólo veinte países han ratificado el Convenio 169, lo cual podría entenderse como una señal de falta de apoyo internacional a los conceptos que consagra. En el caso de Chile, el proceso de ratificación parlamentaria del Convenio se extendió por dieciocho años, culminando sin embargo, con una aprobación mayoritaria. Durante los trámites de ratificación, no fueron analizados los dictámenes pronunciados por los órganos de la OIT con respecto a las medidas de implementación del Convenio 169 emprendidas por otros países signatarios. El análisis de estos antecedentes habría ayudado a lograr una visión más completa acerca de las obligaciones que el Estado de Chile ha asumido al ratificar el Convenio 169.

5) La OIT no constituye una instancia jurisdiccional, con lo cual la supervisión del cumplimiento de los compromisos que asumen los Estados miembros se efectúa en forma más bien declarativa y discursiva. Los órganos de monitoreo de la OIT han emitido una importante cantidad de interpretaciones de las normas del Convenio 169. En este escenario, no se realiza una "condena" de un Estado miembro por el eventual incumplimiento de la normativa convencional. Más bien, la Organización tiende a expresar su preocupación por determinadas situaciones insatisfactorias, solicita a los gobiernos tomar medidas acordes a lo exigido por el Convenio 169 y a entregar la información correspondiente. La OIT tampoco se transforma en un foro natural para recibir las inquietudes de los pueblos indígenas. Dado que no son uno de los poderes constituyentes de la OIT, no pueden intervenir en los procesos de supervisión en forma directa. Con ello, para poder iniciar un procedimiento de queja contra un gobierno requieren contar con el apoyo de las organizaciones de empleadores o, más típicamente, de trabajadores.

6) En la interpretación de la OIT, el Convenio 169 crea obligaciones directas para los países signatarios, las que en términos de 
validez jurídica internacional no pueden quedar aniquiladas por los tecnicismos y restricciones de los sistemas jurídicos internos, aunque en la práctica así sucede. Tal como lo han reconocido las instancias internas de la OIT, la aplicación práctica del Convenio 169 con frecuencia requiere efectuar cambios radicales en las políticas públicas del Estado, lo que impacta amplios espacios territoriales y ámbitos sustantivos. Dentro del vasto abanico de temas que pueden ser adecuados a las normas del Convenio 169, en primer lugar destaca la obligación de efectuar consultas con los pueblos indígenas. Las consultas se entienden como un proceso genuino y continuo de búsqueda de acuerdos que tiene que ser emprendido en forma previa a la adopción de cualquier medida que pudiera afectar a los pueblos indígenas. En segundo lugar, el derecho de propiedad y uso de tierras y recursos naturales ha tenido una interpretación "literal" por parte de la OIT. En otras palabras, por el hecho de la ratificación del Convenio 169, el Estado signatario reconoce tales derechos de los pueblos indígenas. En la medida en la que el Estado no implementa mecanismos específicos para que puedan hacer valer aquellos derechos, incurre en incumplimiento de sus obligaciones derivadas del Convenio 169.

7) La implementación del Convenio 169 en los países objeto de estudio - Noruega, México y Argentina - siguió los mismos patrones de temas sensibles que han provocado múltiples pronunciamientos de los órganos de la OIT. En particular, se plantearon desafíos ante la necesidad de definir correctamente el concepto de "pueblos indígenas", el alcance del derecho a la autoadministración y los derechos sobre las tierras y los recursos naturales consagrados por el Convenio. Junto con lo anterior, temas complejos corresponden a las políticas y regulaciones adoptadas en el ámbito lingüístico, en relación con el reconocimiento del derecho consuetudinario y en materia de acceso a la justicia.

8) En Noruega se optó por instaurar un parlamento indígena a través del cual se canaliza la participación del pueblo originario en las consultas. Asimismo, se creó un territorio autónomo, en el cual se asienta la mayoría de la población indígena. Dicho territorio posee un sofisticado sistema de administración, en el cual el pueblo originario participa prácticamente en condiciones de paridad con las autoridades estatales. Sin embargo, el carácter sofisticado de este sistema es considerado una limitante a la emergencia de un verdadero autogobierno de los pueblos indígenas, no estando el esquema exento de críticas. 
9) En el caso de México existen importantes avances en materia de regulación de los derechos de los pueblos indígenas. Al mismo tiempo, la principal forma de velar por sus intereses consiste en un despliegue de numerosas acciones, coordinadas por un órgano central no representativo de los pueblos indígenas. A diferencia de Noruega, el énfasis de las políticas públicas no parece estar puesto en la consulta o participación, sino más bien en promover la educación y respeto de las lenguas originarias. Asimismo, en una sociedad que se declara como plurinacional a nivel constitucional, el tema del derecho consuetudinario indígena adquiere particular relevancia.

10) En Argentina, el ente promotor de las políticas indígenas tuvo un largo proceso de constitución, retrasándose así la implementación de cualquier tipo de medidas. Hoy en día, los temas más polémicos para ese país son dos aspectos intrínsecamente relacionados: en primer lugar se plantea la necesidad de regularizar el reconocimiento del estatus legal preexistente de los pueblos indígenas. En cambio, su capacidad de actuar en calidad de sujetos de derecho no debe depender de la emisión de un acto constitutivo de una autoridad. De lo anterior se deriva la posibilidad de la que deben disponer esos pueblos para hacer valer sus derechos sobre las tierras. Ante los pocos avances en la materia a nivel de las provincias argentinas, el Congreso del país recurrió a la aprobación de una ley de emergencia que debiera facilitar la implementación de las obligaciones correspondientes.

11) A pesar de que se pudiera cuestionar la legitimación de la OIT para regular el tema de los derechos indígenas, la conclusión del proceso de su ratificación por parte de Chile indica, desde un punto de vista jurídico y legitimatorio, que este Estado comparte los valores jurídicos plasmados en los preceptos del Convenio 169. Desde la entrada en vigor del Convenio 169, Chile se encuentra sujeto a las obligaciones internacionales que asumió en virtud del mismo, cuyo cumplimiento será revisado y exigido por la OIT. Si bien es un sistema que carece de medios para ejecutar sus dictámenes, posee herramientas para vocalizar los incumplimientos que detecta. En este contexto, una postura de respeto hacia el derecho internacional exigiría que la implementación del Convenio 169 se hiciera tomando en cuenta las interpretaciones que han hecho los órganos de la OIT, tratando de evitar caer en la intención de "domesticar" los preceptos de un tratado internacional, ajustándolos a la 
comodidad del sistema jurídico nacional, pues para ello bastaba con no ratificar el Convenio.

Tal como lo demuestra el lenguaje frecuentemente crítico de los dictámenes de la OIT, una implementación precisa de los altos estándares del Convenio 169 constituye una labor sumamente compleja, que sin duda podrá afectar internamente materias económicas, educacionales y jurídicas. Sin embargo, los cuestionamientos que plantee la OIT a través de sus informes permanecerán válidos, antes que nada, en el contexto del derecho internacional y sólo podrán impactar las políticas públicas del Estado de Chile por intermedio de las decisiones soberanas de sus poderes legislativos y administrativos. La pregunta que aún permanece abierta dice relación con la eventual aplicación directa del Convenio 169 por parte de los tribunales de la República. En ellos recaerá finalmente la responsabilidad de determinar si, bajo el sistema jurídico chileno, el Convenio 169 entrega a los pueblos indígenas derechos exigibles ante los tribunales nacionales.

\section{BIBLIOGRAFÍA}

Alston, Philip y James Heenan. "Shrinking the International Labor Code: An Unintended Consequence of the 1998 ILO Declaration on Fundamental Principles and Rights at Work?". CHRGJ Working Paper, No. 10, 2004, pp. 5-33.

Anaya, James S. Los Pueblos Indigenas en el Derecho Internacional. Madrid: Trotta, segunda edición, 2005.

Barber, Keith. “'Indigenous Rights' or 'Racial Privileges': The Rhetoric of 'Race' in New Zealand Politics". The Asia Pacific Journal of Anthropology, Vol. 9, 2008, pp. 141-156.

Bazán, Victor. "Los Derechos de los Pueblos Indígenas en Argentina: Diversos Aspectos de la Problemática. Sus Proyecciones en los Ámbitos Interno e Internacional". Boletin Mexicano de Derecho Comparado, Vol. 108, 2003, pp. 759-838.

Beaucage, Pierre y Rosa Cusminsky. "La Condición Indígena en México". Revista Mexicana de Sociología, Vol. 50, 1988, pp. 191-211.

Benson, Wilfrid. “An I.LO. Pattern for Pacific Territories”. Pacific Affairs, 1944, pp. 311-319.

Borrows, John. "Ground-Rules: Indigenous Treaties in Canada and New Zealand". New Zealand Universities LMW Review, Vol. 26, 2006, pp. 188-212.

Carmona Tinoco, Jorge Ulises. "La Incorporación de los Derechos Humanos en las Constituciones Locales Mexicanas". Memorias del Seminario la Armonización de los Tratados Internacionales de Derechos Humanos en México, 2005, pp. 67115, www.bibliojuridica.org/libros/libro.htm?1=2481. 
Comisión Nacional para el Desarrollo de los Pueblos Indígenas (CDI). La Vigencia de los Derechos Indígenas en México 2007. México: CDI, 2007, http://www.cdi. gob.mx/.

_ Acciones de Gobierno para el Desarrollo Integral de los Pueblos Indígenas Informe 2008. México: CDI, 2009, http://www.cdi.gob.mx/.

Chamosa, Oscar. "Indigenous or Criollo: The Myth of White Argentina in Tucumán's Calchaquí Valley". Hispanic American Historical Review, Vol. 88, 2008, pp. 71-106.

Cornell, Stephen. "Indigenous Peoples, Poverty and Self-Determination in Australia, New Zealand, Canada and the United States". JOPNA, No. 02, 2006, http:// www.ksg.harvard.edu/hpaied, pp. 1-39.

Corntassel, Jeff J. y Tomas Hopkins Primeau. "Indigenous 'Sovereignty' and International Law: Revised Strategies for Pursuing 'Self-Determination'”. Human Rights Quarterly, Vol. 17, 1995, pp. 343-365.

Davis, Megan. "Indigenous Struggles In Standard-Setting: The United Nations Declaration on the Rights of Indigenous Peoples". Melbourne Journal of International Law, Vol. 9, 2008, pp. 440-471.

Del Toro Huerta, Mauricio Iván. "The Contributions of the Jurisprudence of the InterAmerican Court of Human Rights to the Configuration of Collective Property Rights of Indigenous Peoples", en www.law.yale.edu, pp. 1-23.

Díaz, Erica Lily, Nahieli Gómez y Norma González et al., "Estrategias de Defensa para los Pueblos Indígenas”. En Sánchez Matus, Fabián (coord.), Litigio Estratégico en México: La Aplicación de los Derechos Humanos a Nivel Práctico. Experiencias de la Sociedad Civil. México: Oficina del Alto Comisionado de las Naciones Unidas para los Derechos Humanos, 2007, pp. 63-98.

Ewing-Chow, Michael. "First Don No Harm: Myanmar Trade Sanctions and Human Rights”. Northwestern Journal of International Human Rights, Vol. 5, 2007, pp. 153-180.

Fitzmaurice, Malgosia. "The New Developments Regarding the Saami Peoples of the North". International Journal on Minority and Group Rights, Vol. 16, 2009, pp. 67-156.

González Galván, Jorge Alberto, "Los Derechos de los Pueblos Indígenas". Los Derechos del Pueblo Mexicano: México a través de sus Constituciones. México: Senado de la República y otros, 2006, pp. 401-429.

"El Primer Juicio de Amparo en Lengua Indígena: Los Idiomas del Derecho en el México Pluricultural del Siglo XXI". La Ciencia del Derecho Procesal Constitucional. Estudios en Homenaje a Héctor Fix-Zamudio en sus Cincuenta Años como Investigador del Derecho, T. XII, Ministerio Público, Contenciosos Administrativos y Actualidad Jurídica, 2008, pp. 517-530.

Graver, Hans Setter y Geir Ulfstein. "The Sami People's Right to Land in Norway". International Journal on Minority and Group Rights, Vol. 11, 2004, pp. 337377.

Groman, Daniel. "Liberal Internationalism, the League of Nations Union, and the Mandates System". Canadian Journal of History/Annales Canadiennes d'Histoire, Vol. XL, 2005, pp. 449-477.

Helfer, Laurence R. "Understanding Change in International Organizations: Globalization and Innovation in the ILO". Vanderbilt Law Review, Vol. 59, 2006, pp. 649-726. 
Henriksen, John. "The Continuos Process of Recognition and Implementation of the Samiu People's Right to Self-Determination". Cambridge Review of International Affaire, Vol. 21, 2008, pp. 27-40.

Hocking, Barbara Ann. "Land and Natural Resource Management in the Context of International Obligations to Indigenous Citizens: A Case Study of Norway's Finnmark Act". Australian Indigenous Law Reporter, Vol. 53, 2005, en http:/ www.austlii.edu.au.

Hyde, Alan. "The International Labor Organization in The Stag Hunt For Global Labor Rights”. Law \& Ethics of Human Rights, Vol. 3, 2009, pp. 153-179.

Imai, Shin, "Indigenous Self-Determination and the State". CLPE Research Paper Series, Vol. 4, 2008, pp. 1-40.

Josefsen, Eva. "Norwegian Legislation and Administration - Saami Land Rights". Journal of Indigenous Peoples Rights, Vol. 1, 2007, pp. 1-35.

Lightfoot, Sheryl R. "Indigenous Rights in International Politics: The Case of 'Overcompliant' Liberal States". Alternatives, Vol. 33, 2008, pp. 83-104.

Lozano, Claudia. "Indigenous People, Rights, and the State in Argentina". Florida Journal of International Law, Vol. 17, 2005, pp. 603-624.

Macklem, Patrick. "Indigenous Recognition in International Law: Theoretical Observations". Michigan Journal of International Law, 2008, Vol. 30, pp. 177210.

Martin, Lucia. "El INAI-Instituto Nacional de Asuntos Indígenas”, http://www. indigenas.bioetica.org/inves47.htm.

Minde, Henry. "Sami Land Rights In Norway: A Test Case for Indigenous Peoples". International Journal on Minority and Group Rights, Vol. 8, 2001, pp. 107-125.

Pérez Sánchez, María del Pilar. Multiculturalismo: Derecho de Participación Política de las Minorías Indígenas. Zapopan, Jalisco, 2009, http://biblioteca.gdl.up.mx.

Rodríguez-Piñero, Luis. Indigenous Peoples, Postcolonialism and International Law: The ILO Regime (1919-1989). Oxford Univ. Press, 2006.

Speed, Shannon y Jane F. Collier. "Limiting Indigenous Autonomy in Chiapas, Mexico: The State Government's Use of Human Rights". Human Rights Quarterly, Vol. 22, 2000, pp. 877-905.

Standing, Gay. "ILO: An Agency for Globalization?". Development and Change, Vol. 39(3), 2008, pp. 355-384.

Stavenhagen, Rodolfo. "Los Derechos Indígenas en el Sistema Internacional: Un Sujeto en Construcción". Revista IIDH, Vol. 26, 1998, pp. 81-103.

Tennant, Chris. "Indigenous Peoples, International Institutions, and the International Legal Literature from 1945-1993”. Human Rights Quarterly, Vol. 16, 1994, pp. 1-57.

Terborg, Roland, Laura García Landa y Pauline Moore. "The Language Situation in Mexico". Current Issues in Language Planning, Vol. 7, No. 4, 2006, pp. 415518.

Trinchero, Héctor Hugo. "The Genocide of Indigenous Peoples in the Formation of the Argentine Nation-State". Journal of Genocide Research, Vol. 8(2), 2006, pp. 121-135.

Weisband, Edward. "Discursive Multilateralism: Global Benchmarks, Shame, and Learning in the ILO Labor Standards Monitoring Regime". International Studies Quarterly, Vol. 44, 2000, pp. 643-666. 
Wilhelmi, Marco Aparicio. "La Libre Determinación y la Autonomía de los Pueblos Indígenas. El Caso de México". Boletín Mexicano de Derecho Comparado, Vol. 124, 2009, pp. 13-38.

Xanthaki, Alexandra. "Indigenous Rights In International Law Over The Last 10 Years And Future Developments". Melbourne Journal of International Law, Vol. 10, 2009, pp. 27-37.

Zalaquett, José. "La Declaración de Naciones Unidas sobre Derechos de los Pueblos Indígenas". Anuario de Derechos Humanos, 2008, pp. 139-148. 